\title{
MONOGRAPH OF THE GENUS SYNTHEMIS.
}

\author{
By R. J. Tillyard, M.A., F.E.S.
}

[Neuroptera: Odonata.]

(Plates iv.-viii.)

\section{INTRODUCTION.}

The genus Synthemis was proposed by de Selys, in 1871,* in order to receive those species of the subfamily Corduliince in which both the basilar and submedian wing-spaces were reticulated. The type of the new genus was Epophthalmia erstalacta Burmeister. $\uparrow$ De Selys described in his "Synopsis des Cordulines "(1871) five other species of the genus, viz., S. miranda, $S$. macrostigma, S. leachii, S. guttata, and S. brevistyla, besides giving his own description of the type $S$. eustalacta, and pointing out the important differences between it and the other species of the genus Epophthalmia. Three years later, in his "Additions au Synopsis des Cordulines" $(1874) \ddagger$ he added two more species, viz., S. regina and $S$. virgula. The habitat of all these species was Australia, with the exception of S. miranda, whose locality, it is to be feared, will never be ascertained with certainty. The only known specimen of this, the finest and most interesting dragonfly of the genus, was discovered by de Selys, pinned, for ornamentation, into a lady's hat in a shop in Paris. He secured it at once. It is a broken female, lacking five segments of the abdomen. Its locality was stated to be New Caledonia; but though the Museum in Paris is rich in collections from this colony, another specimen has never been taken. It seems, there fore, that the locality is very much open to doubt.

Specimens of the genus continued so rare in collections received in Europe from abroad, that it was not until 1901 that another

* Bull. Acad. Belgique, 1871, xxxi., p.557.

† Handb. Entom. Névrop. 1839.

‡ Bull. Acad. Belgique, 1874, i., p.29. 
species was described, S. Alavoterminata Martin.* Further additions were $S$. primigenia Förster, from New Guinea, $\uparrow S$. nigra Tillyard, $\ddagger S$. cyanitincta Tillyard,§ S. martini Tillyard,\| S. olivei Tillyard, $\mathbf{\Phi}$ s. claviculata Tillyard.** Through the kindness of Dr. F. F. Laidlaw, of London, who has carefully studied the immature and somewhat damaged type of S. leachii Selys, in the British Museum, and has compared it with cotypes of $S$. martini Tillyard, it has been established without doubt that the two are one and the same species. The name martini Tillyard, therefore becomes a synonym of leachii Selys. This leaves fourteen well-established species in the genus. A new species will be described in this paper, together with the hitherto unknown female of $S$. claviculata, which has just come to light.

The insects comprising this genus are among the most beautiful and graceful of Australian Odonata. But papered specimens invariably lose their beautiful colours, and the bright yellow and creamy spots and stripes often fade away into a dull brown. Apparently this has added considerably to the difficulty of identification; for the genus has always been regarded more or less as a puzzle. It was therefore, to me, a great advantage to be able to study them in the field, when I found that some of the most closely allied species differed both in habit and colouration, and could be separated by the eye, even when flying; though, when dried and placed in a collection, the determination was not so easy. I therefore determined to note carefully the colours of each species, and perpetuate them in water-colour. These drawings are reproduced in the two coloured plates attached to the paper. I venture to hope, on the principle that "an accurate drawing is better than the most lengthy and

* "Odonates du Continent Australien," Mém. Soc. Zool. France, 1901.

† Ann. Mus. Nat. Hungarici, 1903.

¥ Proc. Linn. Soc. N. S. Wales, 1906, p.4S9.

$\S$ Loc. cit. 1907, p. 724 .

\| Loc. cit. 1907, p. 726 .

- Loc. cit. 1908, p.747.

** Loc. cit. 1908, p.749. 
detailed description," that even those who have no special knowledge of Australian Odonata will be able to use the plates with advantage.

Owing to the rarity of specimens of the genus, no detailed study of it has been possible to entomologists outside Australia. Doubtless many new species still lie hidden in out-of-the-way parts of the continent. However, during five years' collecting in various localities, I have gathered together a great number of specimens-every one of which has been carefully examined for variation - and have studied their habits in the field. Further, I have been fortunate enough, after long and careful search, to discover, and identify by breeding, the larvæ of no less than five species, the only ones obtainable within a hundred miles of Sydney. The life-histories of these I have worked out fairly completely.

Those who have studied the peculiar venational characters of the wing of Synthemis claim, with justice, that it is the most archaic form of Corduline wing still extant (with the possible exception of the "quadrilateral" genus Cordulephya). I hope to shew in the present paper that the morphology of the larva strongly supports this view. The peculiar character of the Australian fauna is evident in every group, and evidence of it is by no means absent in the Odonata. Such archaic and isolated forms as Synthemis, Petalura, Telephlebia, and Phyllopetalia are of the greatest scientific interest. The study of their lifehistories especially should throw a great deal of light on the present-day affinities of the larger and more dominant groups, and enable us to trace the synthetic evolution of existing types. The peculiar characters of the larvæ of Synthemis, to be described in this paper, are of especial interest, and throw new light on the relationships of Corduliince to other subfamilies.

The objects of this paper are two. Firstly, to discuss the morphological and physiological characters of the group with a view to a satisfactory scheme of subdivision for the genus, and the placing of it in its correct position in the subfamily. Secondly, to give a detailed descriptive account of the separate 
species, their life-histories, larval forms, habits and imaginal characteristics, and to supplement these with dichotomous keys and plates shewing parts used in classification.

I am indebted to Dr. Laidlaw for examining the types of Synthemis in the British Museum; to M. René Martin, of Paris, for knowledge of the types in the de Selys collection, for the information quoted above about S. miranda, and above all for his excellent work on the Corduliince; and to Dr. Ris, of Rheinau, Switzerland, for many valuable hints on field-work, and for his great interest in, and kindly criticism of my new discoveries.

\section{Material StUdied.}

Imagines.-My earliest captures were forwarded to M. René Martin for identification, and he was kind enough to return, with them, some named specimens of his own, which had been compared with de Selys' types. These were specimens of the three closely allied species, S. brevistyla, S. guttata, and S.virgula. In my collection there are two hundred and thirty set specimens of the genus, comprising long series of all the commoner ones. All these have been examined carefully for variation. Besides these, I have examined another hundred or more papered specimens, which have since been sent out to my various correspondents. Of the rare species, I possess two males and three females of $S$. nigra, two males and one female of $S$. claviculata, and two males of $S$. olivei.

I have never seen the unique female type of $S$. miranda, but fortunately it is well figured in M. Martin's "Cordulines," and de Selys' own description is also available. The series of $S$. primigenia possessed by Prof. Förster of Berlin, is also inaceessible; but I have Förster's careful description, and a good figure in Martin's work above-mentioned.

Larva.-During the past two years I have collected and reared a considerable number of larvæ, at various stages of growth, of S. en stalacta, S.macrostigma, and S. guttata. Over fifty of these are preserved in my collection. Of S. regina I have only five specimens, and of S. flavoterminata a dozen. 
The advantage of studying large series in a group subject to considerable variation is self-evident.

The publication of M. René Martin's magnificent "Cordulines, Cataloge Systematique et Descriptif"* in 1906, has brought to all odonatologists the means of studying this subfamily in detail, and is of special value owing to the great rarity of a large number of the species. Its appearance was the signal for renewed interest in the group, and there followed in quick succession two excellent papers on the scheme of classification of the subfamily. I refer to Williamson's "Revision of the Classification of the Corduliince" $\uparrow$ and Needham's "Critical Notes on the Classification of the Corduliince." $\dagger$ Williamson's classification is a great advance upon that adopted by de Selys and retained by Martin. Needham suggests further improvements, bringing the comparative study of the Corduliince to a high degree of efficiency.

All this excellent work contains no attempt at studying lifehistories or describing the earlier stages of the insects, that being outside their avowed scope. The classification has been adopted on the study of wing-venation only. Furthermore, the genus Synthemis has throughout been neglected and left in its Selysian state, owing no doubt to lack of material for the study of it.

In the Williamson-Needham scheme of classification (wingvenation only), the subfamily Corduliince, sens.lat., is divided into two groups, which are themselves elevated to the rank of subfamilies, viz.:-

(1) Macromiince, in which the anal loop of the hind-wing is a compact set of cells, of Cordulegasterine form, i.e., slightly longer than broad, and the hindwing-triangle is never recessed to the level of the arculus.

(2) Corduliina, s.str., in which the anal loop (when present) is very much elongated, and possesses a longitudinal bisector, and the hindwing-triangle is often recessed to the level of the arculus.

* Collections Zoologiques du Baron Edmond de Selys Longchamps, Fasc. xvii., Brussels, 1906.

† Entom. News, Vol.19, pp.428.431, 1908.

¥Annals Entom. Soc. America, Vol. i., No.4, Dec., 1908. 
Under this scheme the genus Synthemis falls, apparently naturally enough, into the subfamily Macromiince. From all the other genera in that subfamily it can be distinguished by the presence of cross-veins in the basilar space.

I have found it hard to believe that there is such a close affinity between the slender, graceful, and timid Synthemis and the coarsely-veined, swift and rapacious Macromia. Apart from the wing-venation, Synthemis is absolutely Corduline in facies, while Macromia is distinctly Eschnine. So much so that, even so acute an observer as Professor Sjöstedt, of Stockholm, has described a female Macromia as a new Eschnid.* There are, in fact, distinct Aeschnid tendencies in the whole Macromiagroup, and it will be interesting to see what light the study of life-histories may throw on this question. I propose, however, first of all, to take the whole question of the wing-venation of Synthemis and Macromia, and to study it in detail. We shall then see where the differences lie.

The essential difference seems to be this. In Macromia we have, in its way, as highly evolved and specialised a wing as is to be found in any dragonfly. I do not mean by this that all parts of the Macromian wing are as highly evolved as in other groups (for instance, the hindwing-triangle is never recessed, nor is the stigma braced); but that the line of development followed has evolved so beautifully perfect and strong a structure for flight, albeit on simpler lines than in some other groups, that it may well stand as a model of perfect development. Nor do I judge it alone by arbitrary standards of development, so much as by its actual test in the field. The flight of Macromia is something to marvel at. When collecting in North Queensland, I found Macromia tillyardi and Synthemis flavoterminata flying on the same creek. The contrast could scarcely be greater. Of the latter, specimens would often fly almost into the net, and their only idea of self-preservation was now and then to rise out of reach of the net, continuing their weak to-and-fro flight undis-

\footnotetext{
* Hylaeschna paludis Sjöst. = Macromia melania Selys $(q)$.
} 
turbed, even when struck at repeatedly. The former came and went like a flash of light, so that one might truly say it was gone before one realised that it had come. During a three weeks' stay, I found the males absolutely uncatchable, while of the females I secured only two.

What, then, makes all this difference between two wings whose venation is on so similar a plan? It is surely that in Macromia every superfluous vein has been eliminated, and the whole strength of the wing-material thrown into its most useful channels; whereas in Synthemis, reduction of cells and cross-veins has proceeded only a little way - not so far, in fact, as in any other Corduline genus. Strong evidence of this is the persistence of the cross-veins in the basilar space-an area of the wing which, above all others, needs to be strong and compact, with no lines of weakness. Stronger evidence still is the excessive variability of wing-venation, which can be seen on examining any long series of Synthemis - not to mention the frequency of absolute "freak-venation," of a kind that I have never seen in any other group. Let us examine this venation in detail.

Cross-veins. - The number of cross-veins in the basilar space varies, in different species, from one to five; in the submedian space, from three to nine. The position of these, especially in the submedian space, is not constant in the same species. For instance, in S. regina male, with five cross-veins, there may be only one beyond the arculus, or two, or one may be directly under the arculus. In the triangles of both wings, which are usually free, cross-veins often occur in one or more of the four wings, and sometimes even there are two cross-veins in a triangle.

Recession of the hindwing-triangle.-This line of specialisation, stated by Needham to be never present in the Macromiince, is almost accomplished (quite in one or two specimens) in Synthemis cyanitincta(Plate vi.). Fig.5 gives the usual position of the arculus, the distance from its base to the inner angle of the triangle being about one-fourth of the whole length of the latter. In all other species the distance is from somewhat under to somewhat over one-half. (Compare the other figures with fig.5). 
Fusion of arculus-sectors.-It is somewhat unexpected to find this character, an evidence of considerable specialisation, well developed in all the species of Synthemis, except perhaps in $S$. cyanitincta,(Plate vi., fig.5) where the sectors fuse quite close to the arculus. The same species, curiously enough, shews the greatest specialisation in the recession of the hindwing-triangle!

Anal loop.-The form of this area is of the greatest importance to a correct understanding of Synthemis wing-venation. The ten figures of portions of wings of different species(Plate vi, figs.1-10) are arranged in order of development of their anal loops. In $S$. olivei(fig.1) we have a scarcely formed loop of six cells; in $S$. flavoterminata(fig.2) the same six-celled loop is very distinctly formed. Six-celled loops occur in several other species, but always in males only (see figs.5, 7,9). A characteristic of the females is that their venation is always more reticulate, and hence the number of cells in the anal loop is greater. In $S$. eustalacta (figs. 3 and 4) we have a slightly deeper and larger anal loop, as also in S. guttata(fig.6). All these are of Cordulegasterine or Macromian form. But in S. regina of we find a double looping(fig.9), which I find is constant throughout my series, except for one specimen, which has a large single loop. A double loop is also the constant characteristic of $S$. macrostigma $q$ (fig.8), but in this species the two loops are very unequal, a basal loop of 3-4 cells being followed by a distal loop of twice the depth, more than twice the width, and 12 or more cells. In S. regina 9 we have the remarkable form of three loops(fig.10), a basal one of 3-4 cells, a slightly larger middle one of 6-7 cells, and a distal one of greater breadth, containing 12 or more cells. These three loops occur in all my S. regina $q$ except two; one of which has a small basal loop of four cells, followed by a very large loop of nearly 20 cells (evidently the two other loops fused together), and another has one very large anal loop consisting of all three loops fused together.

This interesting variability of the anal loop throws a strong light on the problem of Synthemis wing-venation. If we look at the anal area of the hindwing of an archaic Aeschnid, say 
Petalura, we see that instead of an anal loop there are nearly straight veins descending from various points of the anal vein itself right to the posterior border of the wing. These can still be traced(see fig.10) in several species of Synthemis, and they form the sides of the anal loops. Such straight veins are, in one way, lines of weakness in a wing, since they make the posterior margin very liable to tear. How quickly, for instance, does the hind-margin of a Gomphine wing wear out! The advantage of the loop is not without many parallels in Nature. A very telling one, it seems to me, can be seen in the difference between the straight veins of the leaves of a monocotyledonous plant and the "archings" of the secondary and tertiary veins in those of a dicotyledonous plant. In the latter no vein that sets out towards the leaf-border reaches it, but arches over on to the next vein; between two arches, another smaller arch will be formed, and so on; the final result being that all border veins run roughly parallel to the margin. Such a leaf is not easily torn or split, whereas a straight-veined leaf splits with great ease. The pressure on the anal area of a dragonfly's wing during flight is probably as great as that of a strong wind on a leaf, and hence the development of loops should be expected, especially in those dragonflies which have a long seasonal range or indulge in long continuous flights. Petalura, though of great size, never indulges in long flights. The Gomphince have a very short seasonal range, and are seldom on the wing. The necessity, therefore, for the development of loops in these insects has scarcely arisen. But in Synthemis, where the seasonal range is quite as long as in most dragonflies (many species that emerge in November last quite to the end of March, and S. guttata may be taken right into May), and when the insects are continually in flight whenever the sun is out, the need for wing-strengthening has been much greater. It points, therefore, to very feeble specialisation, that the group has not yet developed a strong and invariable loop, such as is found in Macromia.

Pterostigma.-A strong braced vein on the edge of the stigma is a sign of high specialisation, and may be seen in the most 
advanced genera of many families. In Synthemis the stigma is usually unbraced, as in $S$. regina (fig.13), but $S$. macrostigma (fig.15) shews a distinct advance towards bracing, while S. claviculata(fig. 14) possesses a bracing vein.

Freak-venation in the Genus.-I do not recall, in any other odonate genus, such remarkable freak-venation as may be found in Synthemis. Especially is this "freaking" to be found in the region of the triangle and arculus, Passing by such small "freaks" as a four-sided triangle, which is especially evident in my series of S. tasmanica, n.sp., and S. cyanitincta, I come to three remarkable freaks, which I have figured. In the right forewing of a specimen of S. leachii $\hat{\sigma}$ (fig.11), and in the same wing of a specimen of $S$. cyanitincta $q$ (fig.12), I find a freakvariation of the triangle which is of especial interest, as being almost exactly a reproduction of the venation, in this region, of Karsch's remarkable Pentathemis membranulata. The venation of that peculiar inscet is, apart from the triangle, almost exactly that of an Aeschnosoma, and I suggest that the single typespecimen (a female) described by Karsch is nothing more nor less than a freak of that genus. If, in the twenty specimens of $S$. leachii and in the dozen of $S$. cyanitincta taken by myselfboth series from the same district, and during the same fortnight - two such freaks could occur, surely it is not a great stretch of imagination to think not only that freaks in single wings are common in this genus, but that a lucky collector might capture one with the Pentathemis triangle in both forewings. Whether variation occurs also in Eschnosoma, sufficiently to justify the application of this assumption to that genus, I cannot say; but it seems at least quite possible. Any entomologist who can get access to the Pentathemis-type should carefully compare the right and left sides of the insect for any other indication of freaking or variation; and any lack of complete symmetry, especially in the right and left triangles, would go a long way towards establishing my contention that this insect is in reality a freak.

The freak figured in fig.16, from the wing of a male S. regina, is so extraordinary, that $I$ doubt if the different veins can be 
singled out at all. I figure it simply to show to what extraordinary lengths variation may go in this unstable genus.

To sum up, I think the following conclusions may be fairly deduced from the study of Synthemis wing-venation :-

Synthemis is an archaic form, evolving along Macromian lines (as regards venation). Variation and "freaking" are rampant in the group, shewing that the final and most advantageous form of wing has not yet been attained. The most advanced wingtype in the genus is probably that of $S$. claviculata, with its

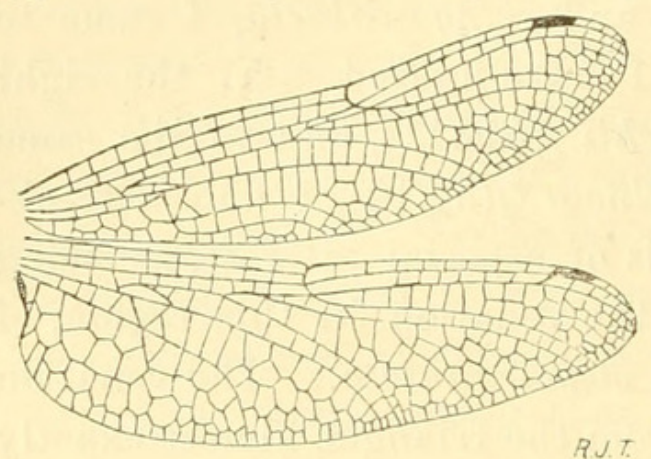
braced pterostigma and scarcity of cross-veins. S. cyanitincta shews a strong tendency to assume the truly Corduline property of a recessed triangle in the hindwing. The oldest forms are probably those with abundant cross-veins, such as $S$. Fig.1-Wings of Synthemis claviculata $(\times 2)$. miranda, $S$. regina, and $S$. macrostigma. In these, there is a more primitive condition of the anal loop, which has not yet become consolidated into a single compact Macromian loop. These are also three of the largest insects in the genus, though by no means the best fliers. The tendency is towards a reduction in size, as well as a reduction in cross-veins. (I am inclined to regard $S$. olivei as an advanced member of the genus, with traces of cænogenesis in the anal loop).

Synthemis is essentially different from Macromia in that, though following on similar lines of development, it is in a far less complete and specialised stage.

In his new work on the Libellulina, Dr. Ris has divided that subfamily into groups having great phylogenetic value. $\mathrm{He}$ places at the beginning of each group the most archaic genus still extant, which contains the essential characteristic of that group, and leads up to the most highly specialised genus in the same group. The result is a series of groups containing widely different forms, but giving a classification undoubtedly of more educational 
value than the usual "linear" grouping of genera. If an attempt be made to unravel the phylogeny of the Corduliince on the same lines, the genus Synthemis might either be placed at the base of the Macromian group, o: it might be deemed worthy of a separate group, in which the genera to be proposed as subdivisions of it in this paper will also be found to be of distinct phylogenetic value.

Let us now turn our attention to the larval forms of Synthemis, the discovery of which should, I think, supply us with evidence of at least coordinate value to that of the wing-venation. (Descriptions of the larvæ of five species of Synthemis will be found below, pp. 340, 348, 355, 363, 370.)

The line of specialisation so well known in Corduline nymphs, viz., the rounded and smooth body, somewhat triangular and pointed front to the head, and long spider-like legs, is found developed to its greatest degree in nymphs of Macromia and allies. In these nymphs the abdomen is almost circular in outline; the head has developed a prominent frontal horn of pyramidal form; and the legs are exceedingly long. Now if Synthemis were really so close an ally of Macromia as has been supposed, we should expect a somewhat similar larval development. But the contrast between the nymphs could scarcely be more striking than it is. The nymphs of Synthemis are absolutely unlike any other known Corduline nymphs. Their principal characteristics are-an elongate-oval body, exceedingly villose; strongly divergent wing-cases; head very square in front, with small prominent eyes projecting from the antero-lateral angles; and rather short, thick legs. The general shape of the nymph, especially the head, recalls at first sight the Orthetrum-group of larvæ in the subfamily Libellulince. But as these two groups are quite distinct in such important characters as the labium and form of wingcases, it is probable that a great deal of superficial resemblance is simply due to the convergence of adaptive characters, brought about by similar conditions of living.

The nearest ally to the larva of Synthemis is most certainly that of the European and American genus Cordulegaster. Thanks 
to the kindness of Dr. Ris, I have been enabled to study, from his own excellent photographs, the nymph of Cordulegaster annulatus, the commonest European species. The resemblance between it and the nymph of Synthemis eustalacta, for instance, is extraordinarily close. In both nymphs the head is of the same shape, with square front, prominent eyes, and rounded hind-lobes; the wing-cases of both are strongly divergent; the legs of both are much shorter, in proportion to the size of the larvæ, than in any Cordubine nymph; the abdomens of both are villous, elongateoval, and rather rounded than flat underneath. In general appearance the Synthemis nymph is shorter and broader-more thickset-than the Cordulegaster nymph; but this is almost the only difference.

In Cordulegaster the antennæ are seven-jointed, with two basal joints thickened and rather rounded, the other five being filiform. The same is true of the antennæ of Synthemis(see Plate viii., fig.4), which are also very hairy. (I cannot say, from the photos, whether those of Cordulegaster are also hairy, but it is highly probable in so villous a nymph).

A comparison of the labia of the same two nymphs shews that both are of the recognised Corduline form, with subtriangular mentum, broad lateral lobes, furnished with a terminal spine, and strongly dentate along the distal border. Large setæ are also developed both on the mentum and on the lateral lobes. The dentition of Synthemis eustalacta (see Plate ix., fig.1) is much smaller and more regular than that of Cordulegaster, the nearest approach to which may be seen in Synthemis macrostigma (Plate ix., fig. 3). In the position of rest, the labium is similar in both, the mentum and lateral lobes forming together a large cup-shaped or almost hemispherical cover to the underside of the head (see Plate viii., fig.3).

This remarkable similarity between the nymphs of Synthemis and Cordulegaster is of great phylogenetic importance, for it supplies the missing link between the two great divisions of the Anisoptera - the Eschnidae and Libellulidce. Of the Eschnida, Cordulegaster alone-shewing no trace in its imaginal develop- 
ment of any Libellulid connection - yet possesses this remarkable nymphal labium of distinct Libellulid form, and distinctly nonEschnid in every particular. We now find that Synthemis, which in its imaginal development is absolutely Corduline, without a single Eschnid characteristic, possesses a larva exceedingly similar to that of Cordulegaster. The gap, therefore, between the two large families is in this way completely bridged. If we place the genus Synthemis at the end of the Libellulidce, in the subfamily Corduliince, and begin the Eschnida with Cordulegaster, we have a very good linear connection between the two. Further, if we see in Synthemis and Cordulegaster two of the most archaic survivals in the whole of the Anisoptera, it is to be expected that such forms would shew small divergence compared with the larger and more specialised groups.

The Larval Gizzard.-Dr. Ris has pointed out to me the great importance of the form of the larval gizzard as a character for the systematisation of large groups. In dragonfly nymphs the gizzard is a well-developed organ, lying within the first or second segment of the abdomen, and furnished on its inside with a set of four or more chitinous plates or "folds," carrying an armature of strong hard teeth for the reduction of the food-masses. In the Anisopterid families two main lines of development are found, viz., (1) the Libellulid form, which possesses four plates arranged in bilateral symmetry, i.e., one pair of one form, and one pair of another; and (2) the Eschnid form, in which the four plates are radially symmetrical, i.e., all alike in form. Dr. Ris found an almost exactly similar pattern in all the Libellulid nymphs he examined, both of the Libellulince and Corduliince. But in the Eschnida, where a fair number of archaic forms have been placed, the radially symmetrical development differs considerably in the various subfamilies.

I have carefully examined the gizzard of Synthemis eustalacta, of which a diagram is given below, in Text-fig.2. The diagram was prepared by cutting the gizzard open longitudinally, spreading it out carefully on a glass slide, and placing another lightly above it; so that the teeth are not absolutely flattened, but are viewed, 
as it were, in half-profile. In each of the two inner* folds will be found two large sharply hooked teeth; in each of the two outer ones, there is a thick single tooth, also sharply hooked, but with

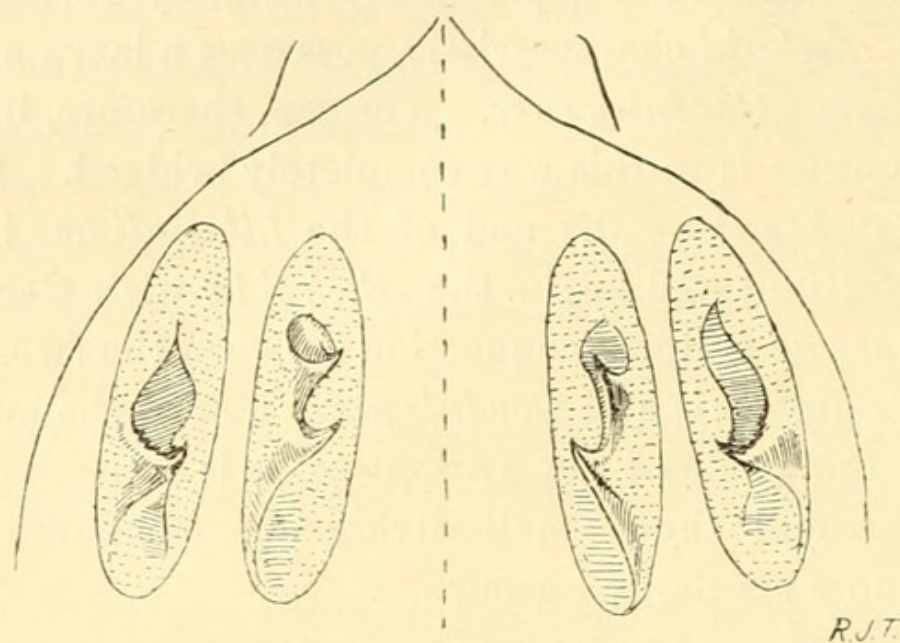

Fig.2-Larval gizzard of Synthemis eustalacta $(\times 25)$.

a strong outer lateral edge carrying four or five small serrate teeth, and indications of two very small serrations on the inner lateral edge. For comparison, I examined the gizzards of two other Corduline larvæ, Cordulephya pygmea and Hemicordulia tau; and one Libelluline larva, Orthetrum caledonicum. They are all almost exactly like that of Synthemis eustalacta, the only difference being in the number of small serrations along the edges of the single tooth. This is a very interesting result, for it proves, beyond all doubt, that the larva of Synthemis, though so closely allied to that of Cordulegaster, is still of the true Libellulid stock.

Another point of great interest is that in the larva of Cordulegaster, although the Eschnid radial symmetry is already established, yet the dentition in each of the four "folds" is very much like that of the two outer folds in Synthemis, viz., a single strong tooth with a serrate edge. This is very unlike the dentition in any other Eschnid group so far examined; in all of which

* The terms "inner" and "outer" refer only to the diagram; the line of section might have been taken in a diametrically opposite position, and then the positions would have been reversed; or another cutting might have given us one pair on each side. 
line of origin of the peculiar Chlorogomphus so as to converge towards Synthemis, since it exhibits a remarkable enlargement of the basal area of the hindwing, which, in its retention of cross-veins, and in the form of its anal loop, bears considerable resemblance to Synthemis.

Such a diagram is not, of course, intended to exhibit accurately the relative ages of the various archaic groups. These can only be ascertained, if at all, by a careful study of their presentday geographical distribution, coordinated with a knowledge of the requisite geological data.

The result of this study of both nymphal and imaginal characters in Synthemis seems to me to demand imperatively a further alteration in the accepted classification of the Corduliince (sens. lat.). There are, in the subfamily, three distinct groups: Synthemis with a distinct non-Corduline tendency in the nymph; Macromia with a distinct non-Corduline (Eschnine) tendency in the imago; and, finally, the Corduliince, s.str., forming the greater part of the subfamily, in which the true Corduline characters of both nymph and imago are developed. I do not suggest the elevation of these three groups into subfamilies, simply because I do not consider that the Corduliince (sens.lat.) can ever be themselves admitted to more than that rank-their Libellulid connection is so close and evident. I would therefore suggest a division of the subfamily Corduliince(sens.lat.) into three main groups as follows:-

i. Larvæ with abdomen considerably rounded, but always longer than wide, smooth; wing-cases parallel; head without frontal horn, subtriangular in front, with eyes well behind the level of the front; legs long and slender.

Imagines with (when present) an elongated anal loop, having a more or less distinct longitudinal bisector; triangle of hindwings very often recessed to, or nearly to, the level of arculus; basilar space always free.......................Group Cordulina.

ii. Larvæ with abdomen very much rounded, nearly circular when viewed from above, smooth, much flattened; wing-cases 
parallel; head with a prominent pyramidal frontal horn; legs long and spider-like.

Imagines with a compact anal loop, very little, if at all, longer than wide; triangle of hindwing never retracted towards arculus; basilar space always free. Large insects of strong flight. ......... ..Group Macromina.

iii. Larvæ with elongate-oval body, very villose; wing-cases strongly divergent, head square in front, with eyes projecting from antero-lateral angles; legs short, thick, hairy.

Imagines with anal loop never as long as wide; basilar space always reticulated. Insects of rather weak flight....

Group Synthemina.

Group i. contains over eighty species; Group ii., nearly fifty; and Group iii., only fifteen. But it is inevitable, in any attempt of this kind, that the most highly developed and successful forms should far outnumber the members of a more archaic group. I do not say, however, that we should rest content with Group i., as it now stands. There may be lines of division of equal value to the others still to be found in that group. In particular, a careful study of the life-history of Cordulephya is necessary before we can be content to leave it in the same group as insects of a very different type.

To turn now to the study of the Group Synthemina, consisting of the fifteen species of the genus Synthemis. Various authors have pointed out the need of some subdivision of the genus, but the attempts made were only tentative, mainly from lack of material to study the group as a whole. Prof. Förster, when describing his new species, $S$. primigenia from New Guinea, noticed the remarkable difference in the female sex-organs of this species and those of S. brevistyla. Apparently he had no knowledge of the type S. eustalacta, However, he suggests a subdivision into two genera as follows:-

o. Without ovipositor and conspicuous appendages : 8-10 lying in one straight line; 8 clipped off straight behind. ............... 
Q. With 8 cut off slantingly, 9 and 10 bent upwards, and a long ovipositor. .................Palcosynthemis (S. primigenia).

$\mathrm{He}$ adds a note to the effect that, owing to the great rarity of specimens of Synthemis in collections, he cannot classify the other species.

Of course, such a division, from a knowledge of two species only, could scarcely be expected to be of any value for the reception of other species. Let us take, for instance, the type $S$. eustalacta, with which Förster should surely have become acquainted before making his attempt. It possesses an ovipositor, though neither so long nor of so exaggerated a form as that of S. primigenia. However, it must go into Palcosynthemis. Hence the original type of the genus cannot now be the type of either subgenus.* Again, S. regina, a species very closely allied to $S$. eustalacta, possesses no ovipositor, and would therefore go into Eusynthemis with S. brevistyla, with which it has very little affinity.

Apart from any other reason, the excessive rarity of the females of these insects is a strong reason for not employing the female sex-organs in generic subdivision. But a study of the ovipositors of the various species will, I think, convince us that they are only of very limited value in this case.

First of all-and this is suggested partly by Förster's diagram of S. primigenia Q-it is necessary to remark that great variability exists in the appearance of the end-segments. Females of Synthemis, on emergence, are very flabby, and remain so, in their retirement, for long periods, with not only the three end-segments. often imperfectly filled out, but with their whole bodies absolutely flat from lack of food. Even if one is fortunate enough to capture a well-developed female (generally one which has been ovipositing), one finds considerable differences in the position of

* See International Rules of Zoological Nomenclature, Art. 29. "If a genus is divided into two or more restricted genera, its valid name must be retained for one of the restricted genera. If a type was originally established for said genus, the generic name is retained for restricted genus containing said type." 
segments 9 and 10 with respect to 8 . In some specimens, especially ill-nourished ones, segments 9 and 10 are piled up somewhat as in Förster's diagram, but I doubt if it ever is so in a well-fed specimen, even of $S$. primigenia. Though, in all those species possessing an ovipositor, segments 9 and 10 are-seen laterally-much narrower than 7 and 8 , yet, in their proper positions, they lie in a line more or less parallel to, and above, the ovipositor. Förster's diagram apparently represents not only an immature, but even a malformed or damaged specimen, for the end abdominal appendages of segment 10 are entirely lacking !

Variation of the Female Sex-Organs.-We shall see, from a study of every species of Synthemis of which the female is known, that there is an enormous difference in these organs, even in the most closely allied species. There is no doubt that the ovipositor, where still present, has ceased to be used for its original purpose, i.e., no species of Synthemis now uses its ovipositor as a terebra or borer. I have watched five species of Synthemis ovipositing. Three of these possess well-formed ovipositors-S. macrostigma, S. eustalacta, and S. flavoterminata. All three lay their eggs in the Libellulid manner, by flying close to the surface of the water, then hovering with body almost vertical, and dipping it with short quick movements, three or four times in succession, into the water, so as to wash the eggs out, several at a time. Females of S. eustalacta, captured in the act of oviposition, have immediately exuded clusters of eggs from ten to a hundred or more in number. (A portion of one of these clusters is figured, greatly magnified, in Plate viii., fig.1). Females of S. macrostigma, however, captured in the same way, exude only two or three eggs in a cluster, and sometimes none at all. These, also, sometimes support themselves by holding lightly to a reed-stem, while still hovering with their wings, and dipping their abdomens in the usual way. $S$. flavoterminata-and the two species, S. reginc and S. guttata, which do not possess ovipositors-all oviposit while flying rapidly to and fro over the water, and wash out their eggs in large clusters. 
Probably the ovipositor-especially when it is curved, as in S. leachii (Plate vii., fig.18) - is still of some use in controlling the escape of the exuding egg-masses. This may account partly for its retention in so many species, long after its original use has gone.

In $S$. flavoterminata, there is a remarkable variation in the length of the ovipositor, compared with the end-segments, in fully developed females. In Plate vii., figs. $22 a, b$, and $c$, are shewn the ends of three females in my collection. At first sight it looks as if the ovipositor was very variable itself in length and shape; but I think that this appearance is due mostly to change in relative position, and that if the ovipositor of fig. $22 c$ could be cut out and measured, it would be very little larger than that of fig. $22 a$, which projects only half as far. Still, this is evidence of variability of the structure in this species, and it may be that S. flavoterminata is even now in process of losing a structure already somewhat aborted. Another peculiarity in the ovipositor of the same species is, that it carries at its tip a small transparent glutinous mass. This is present in all my specimens (twelve), and therefore is not likely to be a remnant of the sticky substance which holds the eggs together. Its use appears to be to supplement the short ovipositor in holding the egg-masses back from too rapid exudation.

I have figured in Plate vii., the end-segments of the females of eight species. Next to S. primigenia, the longest ovipositors are possessed by the four species S. macrostigma(fig.17), S. leachii (fig.18), S. eustalacta(fig.19), and S. tasmanica(fig.20). These represent the most primitive form of the organ still existing in Australia. We then have in S. flavoterminata (fig. 22 ) a considerably shorter and more aborted ovipositor. Passing on, we come to $S$. regina(figs. $16 a$ and $b$ ) - a species very closely allied in other respects to the $S$. eustalacta-group-with only a small remnant of an ovipositor left; $S$. cyanitincta(figs.21a and $b$ ) with a still smaller remnant; $S$. claviculata (not figured) with a similar tiny remnant; and finally, to the closely allied group of four species, S. brevistyla, S. virgula, S. guttata, and S. nigra(see fig.23), in 
which the ovipositor has completely disappeared, leaving the ninth segment hollow without any prominent covering from the underside of 8 .

It thus appears that the female sex-organs are, in this group, too variable to be of much use in generic separation. The groupof four species last-mentioned is the only one in which I propose to use it as a generic character.

Male Sex-Organs.-Throughout the group the primary sexorgans of segment 2 are not prominent, the sheaths being fairly large and well-rounded and forming an effective protection to the penis, which is deeply recessed between and below them(see Plate vii., fig.15). The form of the penis itself is probably only of specific value, varying, no doubt, considerably with the variation already described in the female sex-organs. In any case, as the specimen has to be sacrificed in order to examine it, it is inadvisable to use it in classification. However, I have figured the penis of three species typical of the three genera into which I propose to subdivide the group. The general shape is somewhat the same in all three; but in S. eustalacta(fig.24) there is a long curved filament projecting from the base, followed by a row of hairs decreasing in size; in S. guttata(fig.25) this filament is absent, and the hairs are more numerous, but shorter; in S. flavoterminata(fig.26) the filament is absent, and the hairs few. On the upper part, S. eustalacta possesses a long curved filament similar to that on the base; S. guttata a shorter one, nearly straight; and S. flavoterminata the merest rudiment of one. I have been unable to spare specimens from the rarer species to carry this investigation further; nor do I think it of much value towards forming a really useful classification of the group.

We now turn our attention to the secondary male sex-organs, i.e., the anal appendages of the abdomen, used as claspers in holding the female. These are figured for every species (except S. miranda, of which the male is unknown) in Plate vii., figs.1-14. We find here three distinct groups, each of which is associated with a corresponding form of the abdomen. In the first group (figs. 1 to 8), the superior appendages are long, and more or less wavy; the corresponding abdomen is pinched at segment 3 or 4 , 
enlarged at 6 and 7 , and slightly pinched again at 8-9 (except in S. cyanitincta, where 7.9 are uniformly broad). In the second group(figs.9-12) the superior appendages are very short, and slightly forcipate; the corresponding abdomen is shorter, not very pinched at 3-4 (except S. nigra). In the third group(figs.13-14), the superior appendages are of medium length,slender and straight; the corresponding abdomen is exceedingly slender and cylindrical. (In the coloured Plates, figs.1-7 belong to group 1, 8-11 to group 2, 12-13 to group 3 ; S. nigra, fig.9, has an abdomen varying in shape, but the most slender specimen has been figured in order to contrast more strongly with S. guttata, fig.8).

As already shewn, there is very little in the wing-venation which is really constant enough to be of value in subdividing the genus. There is, however, one character, not yet mentioned, which seems to me to be of considerable importance, and that is the form of the membranule in the hindwing. Nearly all Corduliince possess this membranule as a rather narrow, elongated, and often darkened, membrane at the base of the anal vein; in the male reaching some distance along the border of the anal triangle; in the female attached to the corresponding curved anal border. Now in the two species $S$. flavoterminata and $S$. olivei, the membranule is so reduced as not to be visible to the eye, and the anal triangle of the male has developed a slight convexity of its outer border, instead of being slightly concave, as it is when the membranule is present. These two species form group 3 above-mentioned. So that, with their slender bodies, thin straight appendages of medium length, and this peculiarity in wing-venation, they are sufficiently distinct from the main body of species to warrant a new generic name. There is also another important difference between them and the rest, and that is the size of the front of the head, which is only about half the width of that of any of the remaining species. I propose, therefore, on the strength of these characters, to separate out S. flavoterminata and S. olivei, and to place them in a new genus, Choristhemis.* The type of this genus will be S. flavoterminata Martin.

* Greek $\chi \omega \rho$ ís without, in allusion to the absence of membranule. 
In studying the remaining thirteen species, we can at once pick out a homogeneous group of four (group 2 above-mentioned) characterised by the short anal appendages of the males, the absolute loss of the ovipositor in the females, and the generally rather shorter and less constricted abdomen. These are $S$ brevistyla, S. virgula, S. guttata, and S. nigra. I regard these as the most advanced members of the group Synthemina. Their venation is more open and less inclined to variation than that of the other species, and in the complete loss of the ovipositor, they have at last reached an invariant stage. These four species are also very much more closely allied to one another than any other two species outside them. I therefore propose to place them in a new genus, Metathemis, of which the type will be S. guttata Selys.

There now remain nine species (including the imperfect femaletype, S. miranda Selys, which is retained next to S. regina, to which it is closely allied in venation), in which the superior appendages of the male are always long and wavy, the membranule always present, the front large, and the abdomen long, pinched at $3-4$, and (except in the smallest species, $S$. cyanitincta) somewhat narrowed again at 8 or 9 . Of these, the female of $S$. primigenia possesses an enormously long ovipositor; the ovipositors of S. eustalacta, S. tasmanica, S. leachii, S. macrostigma are large and conspicuous; that of $S$. regina (closely allied in other respects to $S$. eustalacta) is very small and those of $S$. claviculata and $S$. cyanitincta almost obsolete. The two latter are otherwise not by any means closely allied, and are from widely different localities. Of all the species it may be said that, in contrast to the four species above separated out, they all possess at least a rudiment of an ovipositor. I propose to retain these in the genus Synthemis (restricted), the type of the restricted genus, of course, remaining S. eustalacta Burm., the original type of the whole genus proposed by de Selys.

I cannot see any advantage in suggesting further subdivision. The nine species just considered form, without doubt, a less homogeneous division than the other two, but they are in many ways very closely allied, and are certainly the most archaic members of the group still extant. 
There is also a corresponding difference between the larval forms (so far as they are known). The nymph of S. flavoterminata is small and of rather slencler build, with a small projecting frontal rectangular plate, fringed with small hairs; that of $S$. guttata is of stouter build, and has a mnch larger almost semicircular projection or plate standing out from the front; those of S. eustalacta, S. macrostigma, and S. regina are of stout build, but possess only a row of hairs on the front and not a projecting plate (see Plate viii., fig.2, S. eustalacta; fig.5, S. guttata). The four species comprising the genus Metathemis are so closely allied, that I have no doubt this frontal plate will be found in the nymphs of the other three, and will form an excellent generic diagnostic for the larval forms.

The classification proposed may now be exhibited as follows:$\left\{\begin{array}{r}\text { Front small, abdomen narrow cylindrical, membran- } \\ \text { ule absent } \ldots \ldots \ldots \ldots \ldots \ldots \ldots \ldots \ldots \ldots \ldots \ldots \ldots \ldots \ldots \ldots \ldots \ldots \ldots \ldots \ldots \ldots \ldots \ldots\end{array}\right.$

Front large, abdomen of variable width, membran. ule present

Choristhemis, n.g.

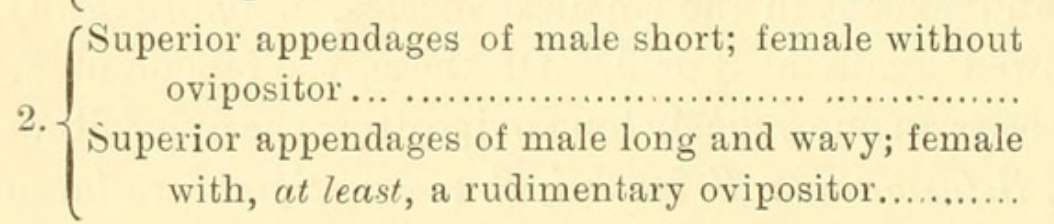

Metathemis, n.g.

Synthemis (s.str.).

And, for the nymphs:-

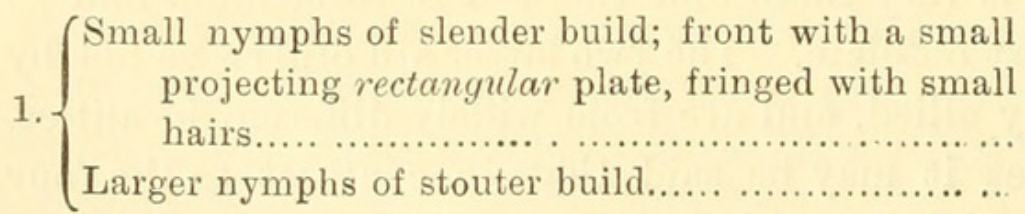

Choristhemis, n.g.

2.

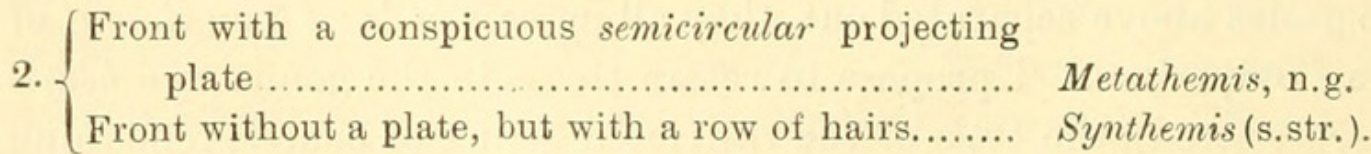

I now pass to the systematic description of the species, arranged in the proposed genera. Where the life-history has been studied, the details of it and the description of the nymph are given under each species. The descriptions of the imagines are taken from freshly killed specimens, and are made as short as is consistent with a full determination of specific differences. 
Subfamily CORDULIIN $Æ$.

\section{Group Synthemina}

Imagines of slender build and rather weak flight. Anal loop of hindwing of compact form, never as long as wide; basilar (median) space always reticulated. Larvæ with head squarish in front, eyes projecting from the antero-lateral corners; legs short and hairy; abdomen elongate-oval in shape, villous; wing-cases strongly divergent; distal margin of lateral lobes of labium distinctly dentate.

\section{Genus 1. S y т т н м i Selys, a me restrictum.}

Membranule present, front large, abdomen varying in width, always pinched at 3 or 4 and widening to 7 . Superior appendages of male long and wavy. Female with, at least, a rudiment of an ovipositor, often with a large and conspicuous ovipositor. Larvæ of stout build, with a row of hairs along front of head, but without a projecting flat frontal plate. Type: Synthemis eustalacto Burmeister.

Key to Species of Synthemis(s.str.).

\section{Males.}

1. $\{$ Thorax with antehumeral spots or stripes.............

\{ Thorax without antehumeral spots or stripes...........

2. Shorax with four creamy antehumeral spots....

2. Thorax with antehumeral stripes.....................

Segment 10 of abdomen with a conspicuous dorsal

3

Segment 10 of abdomen without any dorsal spine or tubercle.

Antehumeral thoracic stripes yellow; colour metallic black with yellow spots.

4. Antehumeral thoracic stripes pale bluish, short; size of insect small, colour brown with pale bluish spots

Dorsal spine black, conical; size of insect large;

5. colours black and yellow............................

Dorsal spine pale yellow, depressed anally.

(Inferior appendage just under half length of superior; colour pinkish-brown with creamy spots

6. Inferior appendage considerably over half length of superior; colour black with a few tiny yellow spots.

Abdomen blackish with bright yellow spots; inferior

7. appendage two-thirds length of superior, truncate

Abdomen dark brownish with paler yellow spots; inferior appendage slightly over two-thirds length of superior, truncate.

(N.B. - The male of $S$. miranda Selys, is unknown.)
3.

2.
3.
S. leachii.
4.
5.
6.

S. claviculata.

S. cyanitincta.

S. regina.

7.

S. macrostigma.

S. primigenia.

S. eustalacta.

S. tasmanica. 


\section{Females.}

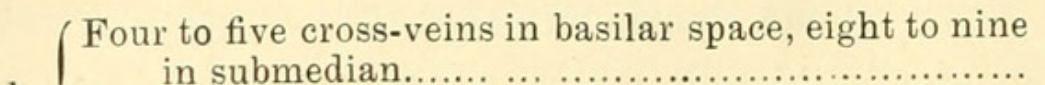
Not more than four cross-veins in basilar space, nor

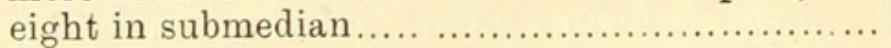

2. Segment 8 with a conspicuous ovipositor...............

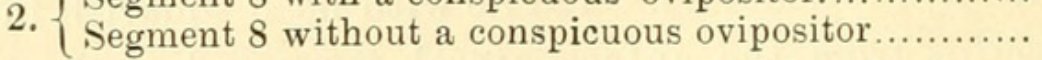

3. $\left\{\begin{array}{r}\text { Ovipositor very long, reaching beyond end of seg- } \\ \text { ment } 10 \ldots \ldots \ldots \ldots \ldots \ldots \ldots \ldots \ldots \ldots \ldots \ldots \ldots \ldots \ldots \ldots \ldots \ldots \ldots \ldots \ldots \ldots \ldots \ldots \ldots \ldots \ldots\end{array}\right.$

Ovipositor not reaching beyond end of abdomen......

(Thorax with a pair of antehumeral stripes.............

4. $\{$ Thorax without antehumeral stripes; colour black

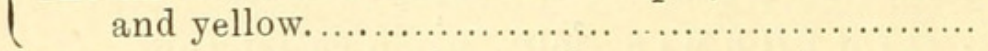

5. Thorax with four antehumeral creamy spots...........

. Thorax without antehumeral stripes or spots... .......

(Thoracic antehumeral stripes yellow; colour metallic

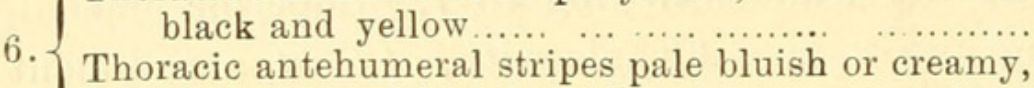
Thoracic antehum of insect small

Lateral thoracic stripe entire.

7. Lateral thoracic stripe broken into a rounded and

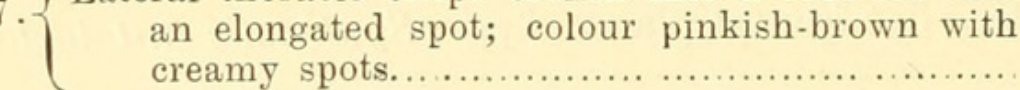

(Appendages in profile rather oval and flat; colour of 8. $\left\{\begin{array}{c}\text { Appendage in profile narrower and more cylindri- } \\ \text { cal; colour of abdomen dark brown with paler } \\ \text { yellow spots; insect smaller than above .......... }\end{array}\right.$
S. miranda.

2.

3.

4.

S. primigenia.

5.

6.

\section{S. regina. \\ S. leachii. \\ 7.}

\section{S. claviculata. \\ S. cyanitincta.}

8.

\section{S. macrostigma.}

S. eustalacta.

S. tasmanica.

1. Synthemis eustalacta Burm. (Plate iv., fig. l.)

Burmeister, Handbk. Entom. Névropt. 1839: Selys, Bull. Acad. Belgique, xxxi. 1871; xxxvii. 1874.

\$. Total length $51 \mathrm{~mm}$., abdomen $38 \mathrm{~mm}$., hindwing $32 \mathrm{~mm}$.

W ing s: Costa yellowish outwards, pterostigma $2.5 \mathrm{~mm}$., dark brown between black nervures; membranule $2 \mathrm{~mm}$., dull grey. Three cross-veins in basilar space, 4-5 in submedian space; all triangles usually free. $\mathrm{Head}$ : Eyes brilliant greenish (when alive), bordered with dark brown, a pale yellow patch behind; vertex hairy, black; front hairy, cleft medially, pale yellow above and on sides, brown on face, black in median cleft; postclypeus brownish, a yellow spot on each side; anteclypeus brownish, touched with pale yellow; labrum yellow edged with brown; labium pale yellowish-grey, mouth edged with dark brown. 
Thorax: Prothorax small, dark brown, a yellow collar in front, a triangular yellow spot behind. Meso- and metathorax deep rich chocolate-brown, a yellow line along dorsal ridge; on either side of it a broad straight steely metallic band; a small bright yellow spot at each wing-base. Sides of thorax with a broad yellow band, bordered above by a narrower steely metallic band; low down, two yellow spots of fair size; notum brown with yellow scutella. A bdom e $\mathrm{n}$ subcylindrical, pinched at 3 , broadening to 8; 9-10 narrower. Colour rich black, marked with pale bright yellow as follows-1, a dorsal spot and two small lateral spots; 2 , auricles yellow, a slanting spot on each side of dorsum; 3, basal half yellow with a somewhat diamond-shaped black dorsal mark, rest black. Segments 4-7 with a pair of small basal spots, a pair of larger central spots, smaliest on 6, larger and of irregular shape on $7 ; 8$ three-fourths covered by a pair of large bright yellow spots, almost meeting along dorsum; 9 with two small basal spots; 10 with a conspicuous pale yellow spine, bent over anally, sharply pointed. A p pend a ges: Superior $3.2 \mathrm{~mm}$., slightly wavy, converging at tips, which are blunt and rounded, almost black; inferior two-thirds as long, truncate, bent upwards. (Plate vii., figs. $1 a, b)$.

ㅇ. A slightly larger and duller insect; wings often tinged with pale brown or yellow, pterostigma $3 \mathrm{~mm}$., pale brownish. Head and thor ax as in male; abdomen stouter, cylindrical; 2 with large oval spots; 3 as in male; $4-7$ with larger basal spots and with central oval spots decreasing in size, smallest on 7 ; 8 , rather short above, with two small basal spots; $9-10$ without spot. Ovipositor $2 \mathrm{~mm}$., reaching to below 10 , conspicuous; appendages $1.2 \mathrm{~mm}$., straight, somewhat flat and oval when viewed sideways, blackish. (Plate vii., fig. 19.)

T y pes: Coll. Germar, Coll. Selys, đ̛̣.

Hab. - New South Wales, Victoria, and South Australia.

Common on bogs and marshes, and sometimes on small running streams, in mountainous districts. Females very rarely seen, in comparison with males. 


\section{Life-History of S.eustalacta.}

The perfect insect emerges about the beginning of November, and continues on the wing until March. Pairing takes place from the middle of November onwards, but it is always difficult to find either pairs in flight or females ovipositing. On a small swamp at Leura, Blue Mountains, where the insect is common, I have watched the female ovipositing in December. When pairing, the male seizes the female in the usual way with his anal appendages, clasping her round the prothorax, with the inferior appendage bent forward over the front of the prothorax. In this position they usually indulge in a wild up-and-down flight, finally flying away into the bush. When a female appears on the swamp there is usually more than one male ready to pair with her, and often quite exciting scuffles occur before pairing is effected. Pairs are also frequently heckled by single males, which sometimes succeed in separating them.

When the female is ready to deposit her ova, she returns to the swamp, flying low, and keeping as much as possible out of the main track of the numerous males flying up and down. However, when she chooses to oviposit right in the track of their flight, they seldom molest her. The place chosen for the eggs is always the same, viz., in still water of from a few inches to a foot or two in depth, overlying deep mud, and close to the main waterdrainage of the swamp. If one dredges such places in the early spring, larvæ of $S$. eustalacta will be found in abundance, but no larvæ of any other species.

Although the female possesses a conspicuous ovipositor, it is apparently of no use to her except perhaps in controlling the exit of the egg-masses. She flies close to the water, along the edges of the reed-beds, continually dipping the tip of her abdomen into the water, so as to wash out the eggs, which fall down and settle on the mud. This is done in characteristic fashion, with the abdomen held nearly vertical and brushed forward at each dip, so as to touch the water gently. Sometimes the action appears to be done easily and not hurriedly, but at other times-- 
particularly when a storm is brewing-I have seen it carried out in great haste, and apparently in considerable trepidation.

A female captured by me, during oviposition, immediately exuded a large cluster of small oval yellow eggs, over a hundred in number. Portion of this cluster is shewn on Plate viii., fig.1. Other females have exuded smaller clusters, and sometimes none at all. There is no doubt that they can be persuaded to wash out ova into a tube of water, while being held in the hand. Unfortunately I was unprovided with one at the time mentioned, so that I have had no opportunity of hatching eggs of this species.

On dredging the swamp late in December, I have found a few very small larvæ, as well as a few fully fed ones not yet emerged. Hence I conclude that the ova hatch out in from two to three weeks (the usual period in the case of other Corduline ova which I have hatched). The larvæ evidently grow rapidly and are full fed within the year. I have taken larvæ in September only half-grown, which, fed up in my aquarium, have emerged before Christmas.

The young larva, which is very hairy, lies nearly buried in the soft mud. In the aquarium, where they are supplied with fine sand, larvæ of all sizes throw up the sand all over them, and scoop out in the process a depression into which they settle, leaving just a slight outline of the body visible, and their eyes and the top of the labium. I am not at all impressed with the power of the labium as a weapon of offence. It is so short in its reach that an insect would have to come very close up to it before it could be captured and eaten. I think that insects and other small water-animals are very seldom captured in this manner, but that often the large cup shaped labium is used to draw in a large quantity of muddy water, which is then sifted and examined by means of the numerous setæ and the terminal hook, and thus a considerable quantity of minute food is obtained.

In one jar'I kept a nearly fullgrown larva without food for some weeks. He never moved his position once. I then introduced, all at once, about two hundred mosquito larvæ. As these 
wriggled past him, he snapped at them again and again. At every three or four tries only, he succeeded in catching one. But so eagerly were they devoured that he accounted for nearly fifty in the course of ten minutes. After that he continued to snap at them occasionally, without apparently any further desire to eat them.

These larvæ are very clumsy, but are capable of running fairly quickly when they have dragged themselves free from most of the surrounding mud. When full-fed, they crawl about on the surface of the mud or sand for days, being all the time only partially covered with mud. They seem quite unable to ascend a stick or stem rising from the water, but crawl out into the sedge or grass first, probably to get drier. Finally they ascend a stem in a most clumsy manner, and emerge in all sorts of curious positions-bent sideways, twisted nearly double, and often nearly upside down. In my aquaria, larvæ would continually get out over the side, and crawl far away into a corner of the room; so that sometimes I found the newly emerged insect on the window-curtain, and never found the exuviæ at all. Others failed to emerge, and the dead bodies of the larvæ were found hidden in all sorts of localities. Only a very few ascended the sticks placed against rocks or wood in convenient positions for them.

Taking the nymphs at random, I have bred an almost equal number of both sexes, the females being slightly more abundant. This shews that the rarity of the female on the swamps is due only to her retiring habits.

The general characters of the nymphs of Synthemis having already been indicated, I now pass to the detailed description of the ovum and the full-fed nymph.

O v u m about $1 \mathrm{~mm}$. long, by $0.8 \mathrm{~mm}$. broad, spheroidal, very slightly pointed at the upper end where it is attached to the main egg-mass. Colour yellow, darkening to orange on exposure to air, and becoming less transparent(Plate viii., fig.1).

N y m p h (fully grown): total length $21 \mathrm{~mm}$., abdomen $15 \mathrm{~mm}$; width of head $5 \mathrm{~mm}$; wing-cases $6 \mathrm{~mm}$. long; antennæ $2.7 \mathrm{~mm}$. Colour dark brown; very hairy(Plate viii., fig.2). 
Head square in front, with small prominent dark eyes at the extreme antero-lateral corners; front fringed with a ridge of irregular hairs; antennce seven-jointed(Plate viii., fig.4), first and second joints from base short, stout and rounded, next four longer and narrower, cylindrical, with pale tips; seventh (apical) joint thin, sharply pointed; all segments furnished with irregular hairs of varying lengths, and great fineness; ocelli inconspicuous, in a small triangle on the rather flat epicranial surface; postocular lobes full and well-rounded, hairy. The back of the head is of irregular surface, so that mud and silt collect in ridges there, giving the appearance, shewn in the Plate, of a slight colourpattern of light and dark brown alternately. (View of head from in front is given in Plate viii., fig.3). Labium, in position of rest, reaching to between the bases of middle and hind legs; length, when closed, to base of mentum, $6.5 \mathrm{~mm}$; median and lateral lobes of mentum when closed forming a nearly hemispherical cup fitting close up to eyes and antennæ; rest of mentum projecting backwards more flatly; indentations of lateral lobes fitting closely, and terminal hooks lying concealed along margin; length of mentum $3 \mathrm{~mm}$., greatest breadth $4.5 \mathrm{~mm}$.; lateral lobes $1.8 \mathrm{~mm}$. to base of terminal hook. Mentum broad, subtriangular, with median lobe advanced to a blunt rounded apex; mental setæ, 5 primary, about $1 \mathrm{~mm}$. long, 4 secondary, 0.2 to $0.3 \mathrm{~mm}$. long, on each side. Lateral lobes subtriangular, outer edge strong, ridged, with tiny stiff bristles arranged irregularly along outer edge; five strong stiff lateral setce springing from the inner side of the ridge, from 1.2 to $0.8 \mathrm{~mm}$. long; terminal hook just above the top seta, very sharp, $1 \mathrm{~mm}$. long; distal border strongly dentate, there being generally seven distinct teeth on each side, unsymmetrical, but arranged so as to fit one another accurately when the mask is closed; teeth rounded, the larger ones tending to overhang slightly on the lower side ("nodding"); largest tooth, generally the middle one on the left-hand side, about $0.3 \mathrm{~mm}$. broad by $0.2 \mathrm{~mm}$. high (Plate ix., fig. 1 ). Thor a : Prothorax short and broad, with protruding lateral angles. Meso- and metathorax well-formed, fairly smooth, dark brown 
above, paler beneath, especially around the coxæ. Legs of medium thickness, rather short; lengths of femur, tibia, and tarsus respectively are-foreleg 3-3-1.7 mm.; middle leg 5-4.5-2 $\mathrm{mm}$; hindleg 6-5.5-3 mm.; coxæ pale, femora dark brown, somewhat hairy, tibiæ dark brown, with longer and finer hairs, tarsi 3 -jointed, with a few small hairs, ending in two rather small weak hooks. Wing-cases flat, hairy, strongly diverging firm bases, so that their tips reach the level of the middle of the sixth abdominal segment, and rest, projecting very slightly from each side of aldomen; forewing-case placed so completely under that of hindwing that only a small portion along the costa is visible. A b d o men elongate-oval, well rounded above, fairly rounded beneath; broadest at segment 6 , then tapering rapidly to end, which appears somewhat pointed; no colour-pattern, but the tralisverse sutures between the segments are rather deeply set under a raised apical ridge of large and conspicuous hairs, giving the body an exceedingly villous appearance, and causing the mud to adhere to it in great quantities: caudal appendages, superior $1.6 \mathrm{~mm}$., sharply pointed, curving slightly downwards; two inferior $1.8 \mathrm{~mm}$, straight, pointed; two smaller laterals, $0.8 \mathrm{~mm}$.; all rather hairy.

T y pes: Coll. Tillyard(Leura, Blue Mountains).

\section{Synthemis tasmanica, n.sp. (Plate iv., fig.2.)}

f. Total length $45 \mathrm{~mm}$., abdomen $34 \mathrm{~mm}$., hindwing $28 \mathrm{~mm}$.

$\mathrm{W}$ in $\mathrm{g} \mathrm{s}$ : costa yellowish outwards, membranule $2.5 \mathrm{~mm}$. long, whitish, anal triangle with a tiny cross-nervule very low down, pterostigma $2.5 \mathrm{~mm}$., pale brown between dark nervures. $\mathrm{H}$ e a d : eyes greenish in the living insect, bordered with dark brown, with a pale yellow mark behind; vertex small, dark brown; front cleft medially, pale yellow above and on sides, rich brown in front; clypeus pale glaucous-brown in centre, livid grey on sides, a livid spot in centre of anteclypeus; labrum and labium shining livid grey, faintly tinged with purple. Th o r a $x$ : prothorax brown, a narrow collar in front, and a dorsal spot, both pale yellow. Meso- and metathorax rich dark brown, a yellow 
line on dorsal ridge, edged on both sides by a broad metallic black band; on each side a straight lateral band of pale yellowish colour, enclosing the mesospiracle, bordered above by a shorter and narrower band of metallic steely black; low down, two conspicuous oval yellowish spots; legs black, underside of profemora partly yellowish; notum brown with yellowish scutella; a conspicuous pale yellow spot at each wing-base. A b d o men : 1-2 enlarged, 3 pinched at base, then widening to 7, 8-10 slightly narrower. Colour: 1, brown; 2, brown, with a slanting pale yellow mark on each side, auricles pale straw-colour, genital opening edged with yellow; rest of abdomen dark brown, marked with pale yellow as follows-3, a pair of semioval basal spots, a pair of larger central spots rather pointed basally; 4-7, with the basal spots smaller, the central spots oval in $4-5$, almost round in $6-7 ; 8$ with two very large dorsal spots, oval, separated by a fine dorsal line; 9 with two small round basal spots; 10 dark brown with a small yellowish dorsal spine depressed anally. A p pendages: superior $2.8 \mathrm{~mm}$., black, wavy, approaching one another at tips, which are blunt; inferior $2 \mathrm{~mm}$., broadly truncate, upcurved, dark brown(Plate vii., figs.2a and $b$ ).

o. Similar to male but slightly larger, especially in expanse of wing. Total length $42 \mathrm{~mm}$., abdomen $31 \mathrm{~mm}$., hind wing $30 \mathrm{~mm}$., pterostigma $2.8 \mathrm{~mm}$.

Head and thorax as in male. Abdomen thicker than in male, almost cylindrical, tapering slightly from base to apex. Colour dark brown spotted with pale yellow as follows - 2, a small basal point low down on each side, a pair of round central spots; $3-7$, a pair of semioval basal spots, a pair of larger oval dorsal central spots nearly touching; basal spots decreasing in size from 3 to 7 , being mere specks on $7 ; 8$-10 very short, 8 with a pair of small oval basal spots, $9-10$ with a transverse narrow band in sutures. Ovipositor conspicuous, reaching to end of 9 , dark brown, tip fairly wide and blunt; appendages $1.5 \mathrm{~mm}$., straight, cylindrical, with rounded tips, dark brown, separated by a rounded projection of 10 which carries a small tuft of hairs (see Plate vii., fig. 20).

Type-series: Coll. Tillyard, đơ (St. Patrick's River, Tasmania). 
Hab.- Northern Tasmania. I took it at St. Patrick's Piver, Launceston, and Cressy, in December, 1908, and January, 1909. I did not find it in Southern Tasmania.

The type-series was taken along the swiftly-running mountainstream, where, no doubt, the larvæ lived. At Launceston and Cressy the insects were found inhabiting swamps-localities similar to those frequented by S. eustalacta on the mainland.

This species is the Tasmanian representative of $S$. eustalacta, the latter not being found in the island. Differentiation from the parent-stock has proceeded far enough, in my opinion, to justify the separation of the island-form as a separate species. A part from its very much smaller size and duller colourationcharacters which in themselves make the two species easily distinguished at a glance, though of little morphological valuethere is a constant difference in the appendages of both sexes. In $S$. eustalacta $\hat{\delta}$, the inferior appendage is just about twothirds as long as the superior; that of $S$. tasmanica $\hat{\delta}$, is larger by comparison, and somewhat more truncate. In S. eustalacta $\&$, the appendages are more leaf-like and less cylindrical than in $S$. tasmanica \%; also the ovipositor of the latter is shorter and more upcurved than that of the former; these differences are clearly shewn in the diagrams of Plate vii.(compare figs.1 and 2, and figs.19 and 20).

The colour-scheme of the St. Patrick's series, when alive, was rich chocolate-brown with pale yellow spots. So different were they from all S.eustalacta I had ever taken, that I never connected the two species until, on examination, I found the depressed dorsal spine on segment 10 of the male. Later, when I took specimens flying on swamps at Launceston and Cressy, I noticed that these had more the colouring of typical $S$. eustalacta. It seems, therefore, that the duller colouration is brought about by a change of living, from stagnant to running water. This is also the case with other members of the group; the brilliantly coloured $S$. macrostigma, S. regina and S. eustalacta are dwellers in slow or stagnant water, while the duller S. leachii and the darkly coloured Metathemis subgroup live in running streams. 
In the coloured plate, the differences of colouration are very carefully shown, and the two species placed side by side for comparison of size also.

\section{Synthemis regina Selys. (Plate iv., fig. 3 ).}

Selys, loc. cit. 1874.

§. Total length $57-60 \mathrm{~mm}$, abdomen $45-47 \mathrm{~mm}$., hindwing $33 \mathrm{~mm}$.

W ings: costa pale yellowish outwards; pterostigma $2 \mathrm{~mm}$., black, membranule $2 \mathrm{~mm}$., narrow, whitish. H e a d : eyes deep green in living insect; vertex black; front hairy, cleft medially, yellow above, marked with a broad black T-mark, the stem of which lies in the median cleft; face of front black, surrounded above and on sides with yellow, the black centre being nearly rectangular; clypeus pale yellow; labrum black, with a pair of pale yellow or creamy spots separated by a black bar; labium pale dirty flesh-colour, gence black, mouth edged with black. Th o r a x : prothorax black, a yellow collar in front, a large yellow mark behind. Meso- and metathorax black or very dark brown with deep metaliic bluish or greenish reflections; a conspicuous yellow line along dorsal ridge; no dorsal bands. On each side a broad band of lemon-yellow enclosing the mesospiracle; below this a narrower band of the dark ground-colour, rest of sides bright yellow; legs black, profemora pale yellow lined with black abuve; underside of metatibiæ ridged with pale grey; notum black, scuta and scutella yellow. A bdomen very long and slender, 1-2 enlarged, 3 very narrow, widening to $7,8-9$ again pinched Colour deep shining black, marked with light lemon-yellow as follows-1, a dorsal spot, also yellow on sides; 2, two slanting basal marks nearly touching, auricles yellow, genital aperture largely surrounded with yellow; $3-5$, a pair of subtriangular basal spots almost touching, a pair of suboval central spots, somewhat pointed basally, separated dorsally by a fine black line; these spots are smallest and closest to base in $5 ; 6$ with basal spots small, central spots flat and distant only one-third from base; 7 nearly all bright yellow, caused by the fusion of two 
enormous central spots; basal spots sometimes present, often obsolete, apical seventh of segment black; 8, a tiny basal dorsal spot sometimes present, a pair of subtriangular spots; 9 black; 10 black, a sharp conical upright dorsal spine, black. A p pendages: superior $3.5 \mathrm{~mm}$., black, fairly straight, tips enlarged both outwards and inwards to a point, forming a barbshaped end; inferior $2 \cdot 2 \mathrm{~mm}$., narrow subtriangular, slightly upcurved(Plate vii., figs. $3 \alpha$ and $b$.)

Q. Similar to male, but with shorter body and larger spread of wing. Total length $52-59 \mathrm{~mm}$; abdomen $40-44 \mathrm{~mm}$; hindwing $36 \mathrm{~mm}$; pterostigma $2.4 \mathrm{~mm}$., black.

Head and thorax as in male. Abdomen thicker, more cylindrical, marked as follows-1, black; 2, black with a pair of irregular slanting yellow spots enclosing a cup-shaped black dorsal area; 3, basal half yellow, enclosing an elongated black diamond-shaped patch, apical half black; 4-6 similar to male; 7, bright yellow all over except last $1 \mathrm{~mm}$. apically; 8 black, a pair of minute yellow spots; 9-10 black, no spine on 10. Ovipositor nearly obsolete; reduced to a pair of separate short black processes (see Plate vii., figs. $16 a$ and $b$ ). Appendages $2.4 \mathrm{~mm}$., black, narrow sublanceolate, pointed.

Types: British Museum and Coll. MacLachlan.

Hab.-Queensland, from the Tropic southwards, New South Wales, Eastern Victoria. Inhabits swamps and slow-running creeks in wooded country.

I have taken this beautiful insect at Gladstone(Q.), in the Sydney district(N.S.W.), and at Alexandra(Vic.). Specimens from the last locality are of great size (one being figured in the plate). There is very little variation in the markings of this, the most beautiful member of the genus.

\section{Life-history of $S y n t h e m i s$ regina.}

In the Sydney district, this fine insect is found in fair numbers on the slow-running and often stagnant Duck Creek at Auburn. It emerges early in December, and is continually on the wing until the end of March. I have found newly emerged specimens 
as late as February. As with S. eustalacta, so with this species, females are rarely met with. I have never seen a pair in cup. Females when ovipositing are very shy. They select the deep shady pools, especially on the tributary creeks, overhung with a dense growth of tea-tree. By creeping cautiously along, on a very hot sunny day, and peering down into these pools, I have several times seen the female ovipositing, but have never been able to capture her. She flies rapidly about, close to the water, brushing the tip of her abdomen against the surface of the pool, and apparently laying a very large number of ova over a very small area. I have never seen her molested by males; indeed the spot chosen is generally too shady and retired for any to be found there.

The larva lives in deep mud in the pools, and is a most unsightly object when dredged out of its lair. If carefully cleaned, it exhibits on the abdomen a slight colour-pattern, shewing a pale dorsal band and pale sutures. The following description is taken from a specimen which I took in the act of emerging :--

Total length $22 \mathrm{~mm}$.; abdomen $13 \mathrm{~mm}$; width of head $5 \mathrm{~mm}$.; wing-cases $6 \mathrm{~mm}$. long; antennæ $2 \mathrm{~mm}$. Colour dark brown; only slightly hairy. $\mathrm{H}$ e a d similar in form to that of the larva of S. eustalactaíq.v.), but smaller in comparison. Labium of exactly similar pattern, slightly smaller; mentum with median lobe advanced to a blunt rounded apex, mental setce 8 primary and 5 secondary; lateral lobes with 7 stiff lateral setce; terminal hook just above the top seta, very sharp; distal border with 7 distinct teeth, similar in form to those of $S$. eustalacta but slightly deeper(Plate ix., fig.2). Th or ax: prothorax broader than head; meso- and metathorax $6.5 \mathrm{~mm}$. wide, rather flat. Legs short, with stout femora, slightly hairy. A bdomen considerably broader and flatter than that of S. eustalacta, ridges of segments less raised and hairs very short, so that the body is comparatively smooth; underside fairly flat; greatest breadth $7.5 \mathrm{~mm}$. at fifth and sixth segments. Appendages: superior $1.3 \mathrm{~mm}$., straight; two inferior $1.5 \mathrm{~mm}$., straight; two lateral $1 \mathrm{~mm}$. , straight; all conical. 
This nymph can be at once distinguished from any of the other four known species by its greater breadth and flatness, and by the coin parative shortness of the anal appendages.

Ty pes: Coll. Tillyard(Duck Creek, Auburn, N.S.W.).

\section{Synthemis miranda Selys.}

Selys, loc. cit. 1871; Martin, "Cordulines," 1906, p.82, figure of wings; Plate iii., fig.19, coloured figure of type-female.

q. Unique. Half of abdomen lacking. Hindwing $44 \mathrm{~mm}$.

As this species is so carefully figured by Martin, I have omitted it from the coloured Plate. From the very detailed description of de Selys, I append the following points for purposes of comparison :-

W ing s very much tinged with russet-brown on their basal halves, especially the hindwing (N.B.-This is a condition often found in newly emerged females); pterostigma $3.5 \mathrm{~mm}$., blackish; membranule very long; smoky; all triangles crossed; 4-5 crossveins in basilar space, 8-9 in submedian. Head steely-black, with yellow markings on clypeus and labrum. Th o rax brown above; two yellow bands on each side. Legs brownish-black. Abdomen slender, steely-black; 2 with a transverse ray, broken dorsally; 3-4 with small basal spots, 3-5 with a pair of round central spots.

Hab. - Supposed to be New Caledonia.

The remarkable discovery of this specimen by de Selys has been already related. It is apparently similar, both in colouration and wing-venation, to the female of S.regina, which is also a large insect. In both the anal loop is divided into three portions; a condition existing in no other member of the genus. But the reticulation of $S$. regina is much less dense than in $S$. miranda. In its suffusion with brown, and in the numerous cross-veins, $S$. miranda recalls a large immature female of $S$. macrostigma. It differs, however, from the latter in having the lateral band of the thorax entire.

I do not think that the presence of cross-veins in the triangles, and the generally dense venation warrants the formation of 
another genus to receive this species. As I have already shewn, cross-veins often occur as "freaks" in one or more triangles of all members of the group, and are especially likely to occur in the more densely reticulated females. From analogy with S. regina, we might expect the male of S. miranda, if it is ever discovered, to have only two divisions in the anal loop, and to possess a much simpler reticulation.

5. Synthemis leachil Selys. (Plate iv., fig. 4.)

Selys, loc. cit. 1871 and 1874; Synthemis martini Tillyard, Pruc. Linn. Soc.N.S.Wales, 1907, p. 726.

The identity of the species described by me under the name "S. martini" with S. leachii Selys, has been established beyond doubt through the kindness of Dr. Laidlaw, who compared cotypes of my series, sent by me to him, with the original type of de Selys. This identity could scarcely have been guessed otherwise, as de Selys' type is an immature and damaged specimen of so pale a colour that it was more like a specimen of $S$ macrostigma, at first sight. Apparently, too, the distinguishing mark of this species, viz., the four antehumeral thoracic spots, were almost obliterated.

The following description is an abridgment of my original one, and contains all the points necessary for a clear understanding of the differences between this and the other species:-

\$. Total length 55-57, abdomen 42-44, hindwing $32-33 \mathrm{~mm}$.

W i n g s : pterostigmx nearly $3 \mathrm{~mm}$, black; membranule nearly $3 \mathrm{~mm}$., pale greyish.

Hea d: eyes bright greenish in living insect, brown behind with a creamy mark; vertex dark brown; front hairy, widely cleft medially, dark brown with a creamy spot on each side; sides of face greyish; clypeus greyish tinged with brown, labrum and labium pale dirty flesh-colour. Th o $\mathrm{rax}$ : prothorax dark brown with a pale mark in front. Meso- and metathorax dark brownish with a metallic tinge; a straw-coloured line on dorsal ridge; four fair-sized creamy antehumeral spots, the two front ones often cleft, the other two usually round. Sides of thorax with a broad 
lateral creamy band, lower part of sides dull greyish; notum brown with creamy scutella; legs black. Four distinct creamy spots at wing-bases. A bdomen pinched somewhat at 3 , also at 8-10. Colour: 1 , brown with a creamy dorsal spot; 2 brown, a pair of slanting basal marks, and top of auricles, creamy; $3-10$ black, spotted with cream as follows:-3-8, a pair of triangular basal spots, and a pair of central roundish spots, the former diminishing from 3 to 8 , being only lines in 8 , the latter rather pointed basally in 3 , round in 4 to 7 , smaller and pointed apically in $8 ; 9$ black, often with two tiny spots; 10 , with a large central oval or diamond-shaped spot, two tiny lateral spots. A p penda ges: superior $3.8 \mathrm{~mm}$., somewhat forcipate at tips, black; inferior $2.2 \mathrm{~mm}$., narrow subtriangular, slightly upcurved, pale brownish with darker tip. (See Plate vii., figs. $5 a$ and $b$.)

‥ Similar to male but somewhat larger; hindwing $35 \mathrm{~mm}$. Wings shaded with brown at bases; pterostigma $4 \mathrm{~mm}$., pale. Head and thorax as in male but somewhat duller in colour, thoracic spots generally larger and more irregular; abdomen cylindrical, broader than in male, with larger spots; 9-10 short and narrow; ovipositor reaching nearly to end of 10 , with a blunt upcurved tip; appendages $0.8 \mathrm{~mm}$., short, straight, black. (See Plate vii., fig. 18).

T y pes : o. British Museum("New Holland"); ㅇ. Coll. Tillyard(Bridgetown, S.W.Australia).

Hab.- - South-Western A ustralia, from Perth to Cape Leeuwin.

It occurs fairly commonly on all running streams and mountain brooks, very occasionally also on freshwater lagoons.

Like all Synthemids, it has an easy flight and is not difficult to capture. In spite of its dull colouration, it is a most beautiful insect when flying; the eyes gleam like living emeralds. Its nearest ally is $S$. macrostigma, from which it is easily distinguished by its slightly greater size, darker colouration, the four thoracic spots, and the larger inferior appendage of the male.

6. Synthemis macrostigma Selys. (Plate iv., fig. 5.)

Selys, loc. cit. 1871 and 1874 . 
De Selys described, in 1871, the type-male from a specimen labelled "Oceania" without any further indication of locality, and the type-female from Fiji. In 1874, he added some remarks on specimens in the British Museum, one labelled "North Australia," another (q) "Swan River," and the rest without any named locality. These he found different in some respects from the Oceanic types.

I have taken a long series on the Blue Mountains, N.S.W., and another series at Bridgetown, W.A. These two series shew considerable differences one from another, and also differ in important respects from the types.

I append the following description from the Blue Mountain series, (of which one male is figured in the plate) :-

๙. Total length $56 \mathrm{~mm}$., abdomen $42 \mathrm{~mm}$., hindwing $32 \mathrm{~mm}$.

W ings: costa pale brownish, a pale point on the nodus; pterostigma 3-5 mm., deep rose-colour; membranule $2 \mathrm{~mm}$., pale greyish. In all four wings a touch of dark brown at base of subcostal space. Head: eyes reddish-brown, a yellow mark behind; vertex dark brown; front dark shining brown in median cleft, pale creamy on sides, so that a rather thick indistinct T-mark is formed; sides of face pale; clypeus brown, a pale triangular spot in middle of anteclypeus, labrum pale brown, or orange, sometimes with two black points, labium pale violetbrown, mouth edged with dark brown. Thor ax: prothorax dark brown, a pale straw-coloured collar in front, a small spot. behind. Meso- and metathorax deep rich chocolate-brown above, with straw-coloured line on dorsal ridge; the dark brown bordered by pale rosy-pink, which curves inwards to the dorsal ridge just above the interalar ridge, forming a beautiful design; sides of thorax rich rosy-brown; lateral stripe broken into two creamy spots, one small and round; the other, enclosing the mesospiracle, narrow elongate; these spots are encircled by a broad lateral band of dark brown which fills the space between them; low down on each side, an elongate creamy mark; notum rich brownish, scutella creamy; legs cinnamon-brown, profemora rosy-pink. $\mathrm{A} \mathrm{bd} \mathrm{omen} \mathrm{slender,} \mathrm{pinched} \mathrm{at} 3$ and again at 9 . Colour rich 
rosy-brown, with black sutures; marked with creamy spots as follows :-1, pale on dorsum; 2, a pair of triangular spots, auricles brown below, paler above, genital aperture edged with cream; 3, a pair of basal triangular spots, a pair of central spots somewhat elongated basally; 4-7, a pair of small basal spots, a pair of oval central spots; 8 , with central spots only; 9 , brownish; 10 brown, pale on dorsum. A p pen d a g e s : superior $3.3 \mathrm{~mm}$., wavy, approaching in a slight curve at tips, which are very slightly enlarged; a tiny spine underneath near bases; colour dark brown; inferior $1.5 \mathrm{~mm}$., narrow subtriangular, pale brownish, tips slightly upcurved (Plate vii., figs. $4 a$ and $b$ ).

o. Very similar to male but somewhat larger, with greater expanse of wing, duller colouration, thicker and more cylindrical abdomen; pterostigma $4 \mathrm{~mm}$., pale yellow in teneral specimens, rich brown in mature ones. Wings hyaline, even in newly emerged specimens, with basal dark brown touch as in male. Ovipositor conspicuous, reaching to middle of segment 10, tip rather blunt, usually scarcely upcurved; very dark brown or black. Appendages short, $0.8 \mathrm{~mm}$., subconical, pointed, dark brown (Plate vii., fig.17).

There is no doubt that this widely distributed species varies considerably in many respects in different portions of its range. I consider that the eastern and western Australian races are sufficiently distinct from one another, and from the oceanic types, to warrant subspecific names. They can be distinguished as follows :--

A. S. macrostigma macrostigma Selys.-Hindwing: fo 33, 우 $32 \mathrm{~mm}$. Black mark at base of wings very small in male, lying in submedian space; very large in female, reaching to arculus of forewings and close up to triangle of hindwings, also in submedian space. Wings of female suffused with yellowish. Front with a conspicuous dark T-mark, face and labrum pale. Appendages of male brown; 9-10 brown. Ovipositor of female, as described by de Selys, very remarkable, reaching nearly to end of appendages, with lamina slightly separated for part of their length, confined again at tips. Types: $\widehat{\delta}$. Coll. Selys("Oceania"): 
q. Coll. Hagen(Fiji). Hab.-Fiji Islands, and probably other Pacific islands lying off the coast of Australia.

B. S. macrostigma orientalis, n.subsp.-Described above. It differs from $\mathrm{A}$ in the following points-Black mark at base of wings very small in both sexes, lying in subcostal space. Wings of female hyaline, without any suffusion, even in newly emerged specimens. (I have bred out several females, all with hyaline wings). Front with a very inconspicuous T-mark; face and labrum darker. Appendages of male dark brown, but dorsum of segment 10 partly pale. Ovipositor of female never reaching to end of 10, generally scarcely upcurved at tip. Type-series: §̊․ Coll. Tillyard(Blue Mountains, N.S.W.). Hab. - New South Wales, Victoria, South Australia, and Tasmania. Found on mountain-swamps; distribution local.

C. S. macrostigma occidentalis, n.subsp.-Remarkable for the small size of the male, hindwing only $28 \mathrm{~mm}$; female as large as in $\mathrm{A}$ and $\mathrm{B}$. Wings of male hyaline, with a conspicuous dark brown basal spot reaching out $2-2 \cdot 5 \mathrm{~mm}$. along subcostal space. Female with wings suffused with yellowish-brown, costa pale yellow, dark basal marks reaching $3.5 \mathrm{~mm}$. in fore- and $6 \mathrm{~mm}$. in hindwing, along subcostal space. Front with a fairly conspicuous brown T-mark, but face and labrum very pale. Dorsum of 9-10 and basal three-fourths of appendages of male very pale. Ovipositor of female reaching just to end of 10 , usually with a blunt upcurved tip, similar to that of S. leachii in Plate vii., fig 18. Type-series: Coll. Tillyard (Bridgetown, Western Australia). Hab. - South-western Australia; very rare. Occurs on swampy creeks. The variability of the ovipositor of this species is a strong argument against the use of that organ for generic distinctions in the group, and serves to support my belief that the ovipositor, where still remaining, is essentially a variable organ in process of reduction from having lost its original use as a terebra.

Life-history of $S$. macrostigma orientalis, n.subsp.

The perfect insect emerges in November, and continues on the wing until February. Immediately the wings are strong enough, 
the insect flies off into the bush, where it may remain for weeks. In some localities where I have taken the full-grown nymph very commonly, I have never yet taken the perfect insect, except just emerging. On very bright sunny days the males fly up and down over the reed-beds and swamps, always keeping low and close to the water. They are very easily captured. Females are very seldom seen. The method of pairing is similar to that of S. eustalacta. I have once or twice secured a pair, in cop., as far as a mile from the breeding-place, in the bush. The female returns alone to the swamp, and selects a part of it away from the main drainage, where the muddy ooze is only just covered with stagnant water. There she lays her eggs, sometimes hovering in the manner of $S$. eustalacta, and sometimes holding lightly to a reed-stem, still keeping her wings in motion, and washing the eggs out on to the mud at its base. On capturing a female during oviposition, I have never found large masses of eggs, but at the most three or four at a time are exuded, and often none at all. So that it seems that this species is less advanced than any other known to me, in its method of oviposition. The fact that the ftmale still clings occasionally to reed-stems, shews that it has not quite lost the instinct of ovipositing in the Eschnid manner. It would be interesting, if the females were commoner, to see if they ever attempt to use their ovipositor as a borer. I have not observed one to do so, but I have seen only half a-dozen females ovipositing altogether.

The young larva, which is very similar to that of S. eustalacta, can always be distinguished at once by its labium, and by the fact that it inhabits quite a different part of the swamp. While the nymphs of S.eustalacta are always concealed in the mud and silt which accumulates close to the main stream or drainage of the swamp, and are always covered with fairly deep water, those of $S$. macrostigma are found only on the outskirts of the swamp, in vile muddy places where scarcely any water remains, and where the mud is very thick and often caked. By scooping out a small "pot-hole" of mud of this kind, only a few inches across, with my hand, I have often secured several fully-grown larvæ. 
The only other inhabitants of these places are the small larvæ of species of Nannodythemis, and it may be supposed that a large number of these fall victions to the large, ugly $S$. macrostigma lymphs

The full-grown nymph, an ugly, cumbersome, mud-bedraggled object, crawls out of its " pot-hole," and often travels some yards before ascending a reed-stem to emerge. In the aquarium, these nymphs are very restless and unhappy. Last year, when I had them in an ordina $y$ aquarium with a foot of water, I succeeded in breeding out only one, though many climbed over the edge and wandered away into a corner of the room to die. This year, I placed them in a flat round tin, a yard in diameter, and just covered the sand with water. Here they have done exceedingly well, and all so far have emerged by ascending the reed-stems placed against the edges. They have, however, the greatest difficulty in climbing, and assume all kinds of absurd attitudes in their efforts to secure a firm hold before emerging.

Ov u im slightly larger than that of S. eustalacta, pale strawcoloured, semitransparent. N y m ph(full-grown) almost exactly like that of $S$. eustalacta in shape, but larger, with a large abdomen, and very dark in colour, some specimens when cleaned being almost black, with paler hairs. Total length 24 , abdomen 14 , breadth of head 6, wing-cases $7 \mathrm{~mm}$. Head dark brown, with frontal tuft of hairs long and matted, postocular lobes hairy. L a bi um very distinct from that of any other known species. (Plate ix., fig.3). Considerably larger than that of $S$. eustalacti. Mentum with the median lobe projecting forward into a distinctly protruding point. Mental setce: 5 primary, 6 secondary. Lateral lobes with 5 stiff setce and a strong sharp terminal hook; distal border very strongly dentate, with four or five large teeth, the lower one rounded (that on the right notched so as to fold over the protruding median lobe), the others rather sharp and triangular; largest tooth $0.7 \mathrm{~mm}$., wide by $0.4 \mathrm{~mm}$. high. Thorax broad, rather hairy; legs fairly long, stout, brownish, very hairy. Measurements of hind-leg, $7+5.5+3.5 \mathrm{~mm}$. Abdomen long, elongate-oval, very dark brown or black, with long fine hairs 
which often gather in tufts when wet. Appendages: superior $1.8 \mathrm{~mm}$., tip curved downwards; two inferior $2.1 \mathrm{~mm}$., straight; two lateral $0.8 \mathrm{~mm}$., straight. In the dentition of its labium, this species shews the closest approximation to Cordulegaster. It is probably as deeply dentate as that of any known Corduline nymph, except Cordulephya. Types: Coll. Tillyard(Leura, Blne Mountains).

\section{Synthemis primigenia Förster.}

Förster, Odonaten aus Neu-Guinea, 1903.

The following abridgment of Förster's description (in German) will be sufficient to give the points of detail in which this species differs from the others:-

5.Abdomen 45-48 $\mathrm{mm}$, hindwing 34-36 $\mathrm{mm}$.

$\mathrm{W}$ in $\mathrm{g} \mathrm{s}$ : costa pale yellow in front; pterostigma $2 \mathrm{~mm}$., black; membranule $2.5 \mathrm{~mm}$., greyish. One row of post-trigonal cells, one cross-vein in basilar space. $\mathrm{H}$ e a d : vertex metallic blue; front cleft medially, metallic blue, lower third yellow; face and labium brilliant brownish-black, base of anteclypeus pale yellowish-green. T'hor a $\mathrm{x}$ : prothorax black, yellow on front and hind borders. Meso- and metathorax brilliant metallic-blue, a yellow line on dorsal ridge; sides with a broad yellow band enclosing the mesospiracle; underside yellowish. Legs short, black. A bdomen very slender, pinched at 3 , broadening to 8, 9-10 narrower. Colour jet black; 2-4, two round yellow dots in middle, traces of same on $5-6$; 8 with a longer yellow spot finely divided dorsally, 7 and 9-10 quite black. A p pendages : superior $3 \mathrm{~mm}$., black, somewhat forcipate towards tips; inferior scarcely two-thirds as long as superior, narrow subtriangular (see Plate vii., figs. $7 a$ and b).

O. Abdomen 47, hindwing $41 \mathrm{~mm}$. Abdomen stouter and morecylindrical than in male, black, with yellow dashes or dots as follows-middle of 2 , each side of base of 3 , two fine dots on middle of 4-6; underside reddish-brown. Ovipositor very long and sharp, extending well beyond the end of segment 10 .

Ty pes : \$. National Museum of Hungary; $\$$ ㅇ․ Coll. Förster (Huon Gulf, Simbang, and Tamai Island, New Guinea). 
Hab.-New Guinea; taken by Karl Wahnes, in March, 1900.

This species, the only known representative of the genus in New Guinea, is quite distinct from all the others, especially because of its very long ovipositor, which seems to be still capable of being used as a borer, judging by its shape. In this character, it is certainly the most archaic member of the group. The species is figured well in Martin's "Cordulines," Plate iii., fig.20, and the male appendages on p.84(fig.98).

\section{Synthemis claviculata Tillyard. (Plate iv., fig.6).}

Tillyard, Proc. Linn. Soc. N. S. Wales, 1908, p.749(ठోonly).

A second male of this rare species, and a female, the latter rather immature, have just been forwarded to me by my friend, Mr. E. Allen, of Cairns. They were taken in the same locality, near Kuranda, as the type-male. As this second male is in very good condition, I have figured it in the plate, and append a brief description.

o. Total length 49 , abdomen 38 , hindwing $32 \mathrm{~mm}$.

Wings: costa pale yellowish outwards; bases slightly saffroned; pterostigma $1.8 \mathrm{~mm}$., black; membranule $2.5 \mathrm{~mm}$, greyish. H e a d deep black, except two large yellow spots on front, two dull yellow spots on labrum. Thorax brilliant deep metallic bluish-green, dorsal ridge and two large antehumeral bands bright yellow; sides with a broad lateral yellow band extending completely across notum; below this a narrow band of metallic greenish-blue, rest of sides and underside yellow. A bdomen blackish marked with bright yellow as follows-1, a triangular dorsal spot; 2, basal two-thirds, auricles, and genital apertures all yellow; 3-6 with a pair of conspicuous central spots, oval in $3-4$, decreasing in size to 6 , where they are round; 7 , with a pair of larger spots close to base; 8, with two very large spots, covering three-fuurths of segment; 9 , two small basal spots; 10 black, apical edge slightly raised dorsally. A p pend a ges: superior $3 \mathrm{~mm}$., black, wavy, slightly clubbed at tips, hairy; inferior $1.3 \mathrm{~mm}$., black, tip upcurved(see Plate vii., figs. $6 a$ and $b$ ). 
Q.(Unique): abdomen 33 , hindwing $34 \mathrm{~mm}$. Wings : bases of forewings beautifully saffroned for $5 \mathrm{~mm}$., those of hindwings for $3-4 \mathrm{~mm}$. Pterostigma $2 \mathrm{~mm}$., black. Head almost completely shiny black, yellow frontal spots much smaller than in male. Thorax deep metallic steely-blue, marked as in male. Abdomen (flat and ill-nourished) broader and more cylindrical than in male, marked with smaller and paler spots. Ovipositor almost obsolete, reduced to a tiny black projection, similar to that figured for $S$. cyanitincta. Appendages $1.2 \mathrm{~mm}$., black, cylindrical.

Types: Coll. Tillyard, $\widehat{\partial}($ (Kuranda, N.Queensland; E. Allen).

Hab.-Apparently confined to one locality near Kuranda. Very rare; January.

9. Synthemis cyaninincta Tillyard. (Plate r., fig.7).

Tillyard, Proc. Linn. Soc. N. S. Wales, 1907, p.7.24.

The following is an abridged description, for comparison with other species :-

5. Total length $41 \mathrm{~mm}$., abdomen $31 \mathrm{~mm}$., hindwing $26 \mathrm{~mm}$.

W ings slightly suffused with brownish, bases slightly saffroned, a black mark for $2 \mathrm{~mm}$. along subcostal space; pterostigma $2 \mathrm{~mm}$., brown; membranule $3 \mathrm{~mm}$., dull whitish. H e a d : eyes green in living insect, bordered behind with white; vertex dark brown; firont deeply cleft, brown, with creamy spots on sides; clypeus and labrum brownish; labium dull brown. 'T horax dark chocolate-brown, a pair of short straight antehumeral stripes, of a pale bluish or creamy colour; sides with a broader lateral stripe enclosing the mesospiracle, and a large patch, low down, of the same colour; notum brown with creamy scutella; legs black, bases of femora brown. A b domen slender, rather short, not very pinched at 3, 7-10 somewhat enlarged. Colour dark brown shading to black, marked with pale bluish spots as follows-2, a pair of semicircular spots; auricles creamy; 3-7, a pair of central dorsal spots, oval or suboval; 8 , a pair of large oval spots; 9 , a pair of small round basal spots; 10 variable, marked with cream or pale bluish; 8 , underneath carries a conspicuous bunch of hairs. A p pend a ges: 
superior $3 \mathrm{~mm}$, slightly wavy, black, pointed; inferior $1.8 \mathrm{~mm}$., brown, narrow subtriangular, tip upcurved (see Plate vii., figs. $8 a$ and $b$ ).

Q. Slightly different from male. Wings often much suffused with brown; pterostigma pale brown; anteclypeus with small triangular creamy spot. Abdomen thicker than in male, cylindrical, rather short, 2-7 spotted as in male, 8 with smaller spots, 9-10 brown; colour of spots and thoracic stripes usually dull creamy. Ovipositor almost obsolete, being represented by a very small projection under apex of 8 ; appendages $1 \mathrm{~mm}$., black, straight, pointed (see Plate rii., figs.21 $a$ and $b$ ).

Type-series: Coll. Tillyard, đ̊q(Margaret River, W.A.).

Hab.- Scattered localities in South-Western Australia. Nargaret River, Armadale, Waroona (a series from the latter locality taken by Mr. G. F. Berthoud). Inhabits small running brooks. December and January.

Easily distinguished from all others of the genus by its small size, pale bluish markings, and the tuft of hairs under segment 8 of male. Allied to S. claviculata in the reduction of its ovipositor, and in possessing antehumeral thoracic stripes, but not in other respects.

\section{Genus 2. Мет а тнанан, n.g.}

Membranule present; front large; abdomen (except in M.nigra) not much pinched at 3, broadened at 8-10. Superior appendages of male short, more or less forcipate, inferior nearly as long. Females with tip of abdomen rounded, no ovipositor, 9-10 not reduced in depth, but short. Larvæ with a conspicuous frontal plate, flat and semicircular, projecting in front between the eyes; build rather stout. Type: Synthemis guttata Selys.

\section{Key to Species of Metathemis (both sexes.)}

1. (A pair of antehumeral thoracic stripes, yellow.

No antehumeral thoracic stripes

M.virgula.

2.

2. Four distinct white or yellow spots at wing-bases........

I No spots on wing-bases

3.

3. $\{$ Lateral thoracic stripe entire

M.guttata.

3. $\{$ Lateral thoracic stripe cut in two, irregular.

M.nigra.

M.brevistyla. 


\section{Metathemis guttata Selys (Plate v., fig.8)}

Synthemis guttata Selys, loc. cit.,1871 and 1874.

A full description of this insect, which is needed to supplement de Selys' descriptions of fragmentary specimens, is here given:-

. Total length 45.50; abdomen 33-37; hindwing $29.32 \mathrm{~mm}$.

W ings: neuration black, open; pterostigma $25.2 .8 \mathrm{~mm}$., black; membranule $2 \mathrm{~mm}$., grey-brown, no spots at wing-bases. $\mathrm{H}$ e a d ; eyes green in living insect; vertex black; front jet black, with two large straw-coloured or creamy spots separated by a very wide black band in median cleft; postclypeus black with a small spot at each side, anteclypeus creamy, or black with two creamy spots, labrum and labium black, mouth touched below with brown. Thor ax : prothorax black; meso- and metathorax very dark brown with dense hairs, dorsal ridge creamy, bordered on each side by a broad black band, indistinct; on each side a broad straight lateral band, entire, and a large patch low down, both creamy or pale straw; notum black, crossed by the lateral creamy band; scutella creamy; legs black, underside of profemora partly pale brown. A b domen enlarged at $1-2$ and 8-10 considerably. Colour black, marked with cream or pale straw as follows:-1, sometimes a triangular spot; 2, two small flat spots, auricles creamy above; 3, two small basal spots, wide apart, two central spots, oval, close together; 4-7, a pair of dorsal central oval spots, very small on $6 ; 8$ with a pair of larger central spots, often pointed apically; $9-10$ black. A p pendages: superior $1.5 \mathrm{~mm}$, black, forcipate, with a small spine on outer border one-third from base; slightly hairy; inferior nearly as long, broad, subtruncate, slightly upcurved. (See Plate vii., figs.11 $\alpha$ and $b)$.

Q. Considerably larger than male, abdomen 34, hindwing 36-38 $\mathrm{mm}$. Wings sometimes suffused with blackish at bases, especially along subcostal space; pterostigma 2.8-3 mm., black. Head blacker than in male, with smaller spots. Thorax and abdomen very dark, almost black; thoracic stripes broad and regular; abdomen broader than in male, cylindrical, 9-10 slightly enlarged, 
marked with creamy spots as follows:-1, a dorsal mark; 2, a sub-basal transverse baud, broken on dorsum; 3, two small basal spots wide apart; $3-7$, a pair of small rounded central spots; 8 , a pair of smaller basal spots; 9-10 black. No ovipositor, central folds of 8-9 wide open as in $M$. virgula (Plate vii., fig. 23). Appendages $0.7 \mathrm{~mm}$., black, straight, pointed, separated, a round hairy tubercle projecting below on 10 .

T y pes: Coll. Selys, ợ("New Holland").

Hab.-Wouthern Queensland, New South Wales, Victoria. Common on fast mountain-streams.

Var.-Specimens from the Illawarra District of New South Wales are of small size, and the male has a pale creamy or strawcoloured labium. I propose to name this var. pallida; it does not deserve subspecific rank.

\section{Life-History of Metathemis guttata.}

The perfect insect emerges in November, and continues a long time on the wing, specimens being occasionally taken as late as May. It is not common in the Sydney district, but I have studied its habits on the Blue Mountain creeks, where it is often abundant. Females are excessively rare compared with males; for instance, I have seen only one pair this year, though I have captured many males. Pairs are usually seen in the bush, away from water. The female returns to the creek alone, and oviposits in a rapid, rather frightened manner, flying quickly up and down the creek, and dipping the tip of her abdomen continually into the water. The eggs are exuded in large masses, and are similar to those of $S$. eustalacta in size and shape, but greyish or dull brownish in colour, semi-transparent.

The larva lives in the clean sand of the clear running mountainstreams. In concealment, it throws up sand over its back, and settles down into a slight hollow, its eyes, frontal ridge and edge of labium, and anal appendages alone being visible. In this position in my aquarium, I have frequently fed it with mosquitolarvæ, which it eats with great avidity. When full-fed, it crawls to the overhanging bank of the stream, and clambers up the 
twigs or stalks of fern and grass that fringe it. It does not experience quite as much difficulty in climbing as do the larvæ of S. eustalacta and S. macrostigma; this is perhaps due to its being free from slippery mud. One or two have climbed straight up out of a deep aquarium and emerged.

In appearance and shape, there is great similarity between the nymphs of $S$. eustalacta and $M$. guttata. There are, however, the followiug important differences-the abdomen of M. guttata is slightly longer, and the hindlegs shorter than in S. eustalacta. There is a conspicuous flat semicircular plate projecting in front, between the eyes, in $M$. guttata (see Plate viii., fig.5). The whole insect is comparatively clean, (from its habit of living) and the abdomen shews a distinct colour-pattern of light and dark brown; each segment carrying a dorsal stripe and a large irregular spot on each side, of a pale colour. The body is less hairy than in $S$. eustalacta, the hairs of the segment $\mathrm{l}$ ridges being few and very fine, generally 4-5 on each side and none on dorsum.

L a b i u m : mentum slightly more triangular than in S. eustalacta; the median lobe with a distinctly protruding central angle, as in S. macrostigma; mental setce, 5 primary, and 7-8 secondary; lateral lobes with six stiff lateral sete, and a sharp terminal hook; distal margin with 6-7 rather flat rounded teeth, the largest being $0.2 \mathrm{~mm}$. wide by $0.1 \mathrm{~mm}$ high (Plate ix., fig.4). A n a 1 a p p end a g es: superior $1.3 \mathrm{~mm}$., distinctly curved downwards at tip; two inferior $1.4 \mathrm{~mm}$., also curvel downwards slightly; two lateral $0.8 \mathrm{~mm}$, straight.

Ty pes: Coll. Tillyard(Leura, Blue Mountains).

\section{Metathemis nigra Tillyard. (Plate v., fig.9).}

Tillyard, Proc. Linn. Soc. N. S. Wales, 1906, p.489.

Since publishing the description of this species, I have received from Mr. F. P. Dodd, of Kuranda, a pair of this species which differ in some respects from the type. These more than ever convince me of the absolute distinctness of this species from $M$. guttata. The following short description is appended for comparison :-

ऽ. Total length 50, abdomen 38 , hindwing $33 \mathrm{~mm}$. 
W in g s: neuration black, very open, costa yellowish outwards; pterostigma $2.5 \mathrm{~mm}$., black; membranule $1.5 \mathrm{~mm}$., dark brown. $\mathrm{H}$ e a d : eyes green in the living insect; vertex black; front dark metallic blue, with two round creamy or pale yellow spots, close together, placed well in front, and bordered on sides by a greyishbrown patch; clypeus black, with two small central pale spots on anteclypeus; labrum b'ack; labium brownish. Th or a $\mathrm{x}$ black with metallic greenish-blue reflections, dorsal ridge creamy or greyish; on each side a broad continuous creamy lateral band, and low down a small spot and larger subtriangular area of same colour. Four distinct spots at wing-bases. Notum black, crossed by the lateral band, scutella creamy; legs black, part of profemora brownish. A bdomen very slender, much pinched at 3 , then broadening to $6,7-10$ narrower ( 8 somewhat pinched in the specimen figured). Colour metallic black with creamy spots as follows -2 , a pair of slanting points; auricles dark; $3-4$, a pair of basal dots and a pair of central dots; $5 \cdot 7$, a pair of central dots only; 8 , two tiny points one-third from base; 9-10 black. (These dots were either obliterated in the type-specimen, which was in poor condition, or else not present). A p pendages: superior $1.5 \mathrm{~mm}$., slightly forcipate, hairy, a small spine on outer margin close to bases, black; inferior nearly as long, broadiy truncate (see Plate vii., figs. $12 a$ and $b$ ).

o A larger and stouter insect, with shorter and more cylindrical abdomen; hindwing $36 \mathrm{~mm}$. Wings suffused all over with russet-brown. Markings of head and thorax as in male but yellow; spots of 6-8 generally obsolete; all spots pale yellow; 10 projecting below in a rounded hairy tuberele. Underside of 8-10 similar to that of $M$. virgula (Plate vii., fig.23); no ovipositor. Appendages $1 \mathrm{~mm}$., hairy, black, straight.

Types: Coll. Tillyard, ô $q$ (Kuranda, N. Queensland).

Hab. - Northern Queensland; not uncommon; November to March.

The colouration reminds one of Synthemis primigenia. Its nearest ally is rather $M$. brevistyla than $M$. gutlata, for it agrees with the former in possessing the four bright spots at wing-bases, 
and in having the frontal spots close together; whereas with the latter it agrees only in having the lateral thoracic band entire. However, in its general shape and appearance it is much the most distinct species of the four comprising the genus.

\section{Metathemis Brevistyla Selys. (Plate v., fig.10).}

Synthemis brevistyla Selys, loc. cit. 1871.

o. Total length 43 , abdomen 32 , hindwing $31 \mathrm{~mm}$.

W in g s slightly tinged all over with pale brownish; neuration closer than in the two preceding species; pterostigma $3 \mathrm{~mm}$, black; membranule $2 \mathrm{~mm}$., greyish. $\mathrm{H}$ e a d : eyes deep green in living insect; vertex black; front black with two large pale yellow spots, separated by a rather narrow black band in median cleft, and extending on to sides, where their colour is more greyish; clypeus black, a central yellow mark on anteclypeus; labrum black; labium pale straw-colour. Thorax very dark brown, dorsal ridge yellow, a deep steely-black band on each side of it; sides steely-black; lateral band completely broken, forming two elongate-oval irregular spots, bright yellow; low down, a small round yellow spot in front, a larger yellow area behind; notum dark brown; scutella yellow; four distinct bright yellow spots at wing-bases; legs black, underside of profemora pale brownish. A b d o m en : 1-2 and 7-10 somewhat enlarged, very dark brown shading to black, marked with bright yellow as follows-1, a dull dorsal mark; 2, two slanting spots and auricles; 3, basal half yellow enclosing an elongate-oval black mark with a fine apical stem; 4-6, a pair of small basal spots, a pair of small central spots; these spots largest in 4 , decreasing rapidly to $6 ; 7$, with small central spots only; 8, a pair of large spots occupying the basal half or more of the segment; 9 , two small triangular basal spots wide apart; 10 black. A p pend a g e s : superior $1.5 \mathrm{~mm}$, black, somewhat forcipate, a small spine on outer margin near bases; inferior not quite as long, broad, nearly black, truncate (Plate vii., figs.9a and $b$ ).

q. Very similar to male, but somewhat larger; hindwing $32 \mathrm{~mm}$, , bases of wings touched with blackish-brown; pterostigma $3.3 \mathrm{~mm}$, , 
dark brown. Head and thorax as in male. Abdomen shorter and stouter, more cylindrical; markings similar to male, but all spots larger except those of 8 , which are slightly smaller; 9 , black; 10, very short, black, ending in a large rounded hairy protuberance below appendages. No ovipositor, underside of 8-10 similar to $M$. virgula (Plate vii., fig.23). Appendages $1 \mathrm{~mm}$., straight, black, pointed, very slender.

Ty pes: Coll. Selys, ộ(immature)(Port Denison, Queensland).

Hab.-Queensland, New South Wales, Victoria; November to March.

It occurs along the larger rivers, often in company with $M$. virgula, but very seldom in the same localities as $M$. guttata. It is especially abundant in Victoria and Southern New South Wales, where the specimens are larger than the Queensland types. The series described above by me, and of which the male is figured in the plate, were taken at Alexandra, Victoria.

\section{Metathemis virgula Selys. (Plate v., fig.11).}

Synthemis virgula Selys, loc. cit. 1874.

o. Total length 49; abdomen 37 ; hindwing $29 \mathrm{~mm}$.

$\mathrm{W}$ in g s : costa bright yellow outwards, neuration more open than in M.brevistyla; pterostigma $2.6 \mathrm{~mm}$., black; membranule 3 $\mathrm{mm}$., pale greyish. H ead: eyes dark green in living insect; vertex black; front yellow, a narrow black band in the median cleft, face yellow above and on sides, a large brown rectangular patch in middle; clypeus and labrum yellow edged with brown; labium pale yellow, mouth touched with brown. Thorax dark brown, with indistinct steely reflections above; dorsal ridge yellow; a pair of bright yellow antehumeral bands, pointed sharply towards interalar ridge; sides brown with steely reflections, a bright yellow lateral band, irregular but continuous; a large yellow patch low down. Notum brown, scutella yellow; a distinct yellow spot at each wing-base; legs black, underside of profemora pale brown. A bdomen, 1-2 and 7-10 somewhat swollen, 3 rather narrow. Colour deep brown shading to black, marked with bright yellow as follows:-1, an indistinct dorsal 
spot; 2, two large spots and auricles; 3, basal half yellow, enclosing a narrow elongated basal oval mark on dorsum, sometimes with a dark apical stem; 4, sometimes with basal half as in 3, sometimes with a pair of basal triangular spots and a pair of central spots, conjoined; 5-6, a pair of basal spots and a pair of central spots, small; 7, basal spots almost obsolete, central spots round and small; 8, with two very large spots occupying the basal half or more of the segment, and very close together; 9 , two large subtriangular basal spots; 10, two smaller roundish spots. A p p endages: superior $1.8 \mathrm{~mm}$., black, somewhat forcipate, no spine at bases; inferior nearly as long, broad, truncate, black. (Plate vii., figs.10 $a$ and $h$ ).

Q. Very similar to male, hindwing $33 \mathrm{~mm}$.; pterostigma $3 \mathrm{~mm}$., dark brown; wings suffused with pale yellowish-brown. Front with brown mark in cleft slightly wider, otherwise head and thorax as in male. Abdomen slightly shorter and more cylindrical, 1-8 spotted as in male; 9 , with smaller spots; 10 , very short, black. Underside of $8-10$ as figured in Plate vii., fig 23; no ovipositor, folds of $\&$ pale yellow, of 9 touched with yellow, rest dark brownish-black. Appendages $1 \mathrm{~mm}$., thin, straight, pointed, black; 10 ending beneath in a rounded hairy tubercle with two sm aller tubercles, one on each side, beneath it.

Ty pes: Coll. MacLachlan, of (Melbourne).

Hab. - Southern New South Wales, Victoria November to March.

It is usually found in the same localities as M. brevistyla, though always in less abundance. The series described above were taken at Alexandra, Victoria.

Genus 3. Cно о I т т н м I s, n.g.

Membranule absent or quite insignificant; front small; abdomen slender, cylindrical. Superior appendages of male of medium length, slender, almost straight. Ovipositor of female variable. Larvæ similar to those of Synthemis, s.str., but smaller and of slenderer build; front with a small rectangular projecting plate fringed with small hairs. Type: Synthemis flavoterminata. Martin. 


\section{Key to Species of Choristhemis.}

Medium size, metallic-black and bright yellow, no

$\left\{\begin{array}{r}\text { antehumeral thoracic stripes........................ } \\ \text { Small size, duller black and creamy, a pair of straight }\end{array}\right.$ antehumeral thoracic stripes.

C. flavoterminata.

C. olivei.

\section{Choristhemis flavoterminata Martin. (Plate v., fig 12).}

Synthemis flavoterminata Martin, Mém. Soc. Zool. France, 1901. o. Total length 46 , abdomen 36 , hindwing $31 \mathrm{~mm}$.

$\mathrm{W}$ in $\mathrm{g} \mathrm{s}$ hyaline in mature insect, tinted with brownish-yellow in teneral specimens; pterostigma $2.5 \mathrm{~mm}$., black. H e a d : eyes bright greenish in living insect; vertex black; front slightly cleft, bright yellow; postclypeus black, anteclypeus yellow; labrum jet black; labium yellowish-brown. Thor ax: prothorax black with a large yellow dorsal spot. Meso- and metathorax metallic steely or greenish-black; dorsal ridge yellow, two round yellow spots near interalar ridge; sides with a broad irregular lateral band, a small round spot low down in front, and a large area on metapleurum, all bright lemon-yellow; notum black, with yellow scutella and scuta; legs black, basal half of profemora yellow. A b d o m e n black spotted with lemon-yellow as follows-1, either a dorsal cross, or a dorsal and two lateral spots; 2, a dorsal cross or fleur-de-lys; auricles yellow; genital aperture surrounded with yellow; 3-4, basal half yellow enclosing an elongated dorsal mark; $5-7$, a pair of small basal spots, a pair of small central spots, both decreasing in size from 5 to $7 ; 8$, two small basal spots or points; 9-10 very variable, but mostly yellow; sometimes clear, sometimes with black suture or spots, or a black W-mark. A p penda ges: superior $2 \mathrm{~mm}$., black, narrow subcylindrical, tips somewhat blunt, downy; inferior two-thirds as long, subtriangular, tip truncate, slightly upcurved, black (Plate vii., figs.13a and $b$ ). Genital aperture of segment 2, viewed in profile, is figured, (Plate vii., fig.15).

Q. Similar to male; expanse of wing greater; wings usually suffused with pale yellowish-brown. Head and thorax as in male, except front, which is black with a large yellow spot on each side." Abdomen cylindrical, much stouter than in male; marked 
as in male, except-2, a yellow dorsal line and a pair of small central spots, 3-7 with bases almost completely yellow; 7 a small dorsal spot; 8 , variable, usually black with an anal yellow spot; 9, variable, usually apical two-thirds yellow; 10, black, sometimes with a pair of yellow spots. Ovipositor black, variable in length, with segments 8-9 also varying in length and position above it; rather short and broad, tip rounded, and carrying above a small gelatinons patch of varying size. Plate vii., figs. $22 a, b$ and $c$, shew the variations of the end of the abdomen; fig. $22 d$ is $22 a$ seen from below. Appendages $1 \mathrm{~mm}$., black, slender, straight; 10 projecting below in a rounded hairy tubercle.

Var.-Besides the variation of the colouration of the end abdominal segments already noted, there is, in North Queensland, a well-defined dwarf form: abdomen 32, hindwing 29; pterostigma $2 \mathrm{~mm}$.; only one row of post-trigonal cells, whereas typical specimens have one or more sets of two cells, followed by single cells, after the triangle. Specimens from intermediate localities shew intermediate variations.

T y pes: Coll. Martin, $\widehat{\jmath} q($ New South Wales).

Hab.-New South Wales and Queensland, from Illawarra to Cape York.

The series described above was taken around Sydney.

Life-History of Choristhemis flavoterminata.

The perfect insect emerges in November, and continues on the wing until March or April. It is found only along densely wooded creeks and rivers, and prefers swiftly running water. The method of pairing and oviposition is similar to that of $M$. guttata, but the eggs are not exuded in such large quantities, and are pale yellowish in colour, The larva lives in the sand at the bottom of the deeper pools, or under the sides of the stream where the bank overhangs and the water is fairly deep. It emerges by climbing up the stalks of fern and grass, often to a considerable height. The full-fed nymph is very dark brown, usuilly fairly clean, but less so than that of $M$ guttata. Owing to its greater villosity, particles of sand and silt often adhere to 
it after emergence. In general appearance it resembles the nymph of $S$. eustalacta, but is much slenderer and smaller. Total length 17; abdomen 9.5 ; breadth of head 4; wing-cases $5 \mathrm{~mm}$. Legs fairly long. Abdomen with rows of curved hairs on each segmental ridge. Labiu $\mathrm{m}$ : mentum rather short with fairly broad base, median lobe triangular, but with no projecting point; mental setce, 6 primary, 8 secondary. Lateral lobes rather small, with six stiff lateral setce and a sharp terminal hook; distal border carrying six well-formed and rather rounded teeth, very similar in shape to those of $S$. eustalacta, but not quite so high. (Plate ix., fig.5). Anal appendages of abdomen: superior $1 \cdot 2$ mm., with tip curved downwards; two inferior $1.4 \mathrm{~mm}$., straight; two lateral $1 \mathrm{~mm}$., straight.

T y pes: Coll. Tillyard (North Sydney).

\section{Choristhemis olivei Tillyard. (Plate v., fig.13).}

Synthemis olivei, Tillyard, Proc. Linn. Soc. N. S. Wales, 1908, 1. 747 .

The following abridged description will serve to distinguish it :-

§. Total length 39 , abdomen 30 , hindwing $27 \mathrm{~mm}$.

W ings: neuration fine, open; pterostigma 1-7 mm., black. $\mathrm{H}$ e a d : eyes grey-green in living insect; vertex black; front dull whitish; clypeus whitish with black sutures; labrum white with a fine transverse black line; labium pale brownish. Thorax : prothorax brown, collar and two dorsal spots white. Meso-and metathorax deep black; dorsal ridge creamy; two creamy antehumeral rays, straight and narrow, followed by two small white spots; sides black with a large lateral irregular mark like the letter " $n$ " flattened, and another patch low down, both creamy. A b d o m e n very slender, cylindrical, black, marked with straw colour as follows-2, a pair of dorsal marks; auricles creamy; $3-8$, a pair of basal spots, and a pair of smaller central spots, decreasing from 3 to $8 ; 9-10$ black. A p p e n d a g s : superior $1.8 \mathrm{~mm}$., slender, straight, pointed, with two stiff hairs at tips, 
black; inferior 1.3 mm., broader, truncate, black, tip upcurved (Plate vii., figs.14a and $b$ ).

ㅇ. Unknown.

Ty pes: Coll. Tillyard, two males(Cooktown, N. Queensland). Hab. - North Queensland. Very rare. Inhabits small mountain-creeks and bogs. December-January.

\section{Appendix.}

\section{Details of malerial examined.}

I append lists of (1) set specimens of imagines; and (2) mounted specimens of larvæ and exuviæ, in my collection. These have formed the main materisl studied for the purpose of this paper. Many other specimens, mostly taken by myself, have passed through my hands, and have been distributed as duplicates; when such specimens came from localities not otherwise included, they are noted in brackets. Unless otherwise stated, the specimens were taken by myself. Specimens bred from larvæ, or taken in the act of emergence, are placed pinned beside the exuviæ, and are not included in List i.-except two Synthemis macrostigma $\&$, which bred out, and were set and placed with the series of imagines.

\section{List i. (Set specimens of imagines).}

Synthemis eustalacta Burm.-Blue Mts., N.S.W.,(Leura) Feb., 1905, 5 males: (Medlow) Jan., 1910, 1 male-Jindabyne, N.S.W., Jan., 1910, 7 males, 6 females-Alexandra, Vic., Dec, 1906, 1 female. Total, 13 males, 7 females. [Other localities, Macedon, Vic.(G. Lyell); Burnside, S.A.(S. Angel)].

S. tasmanica, n.sp.--St. Patrick's River, Tas., Jan., 1909; 3 males, 3 females-Launceston, Tas., Jan., 1909, 5 males : Cressy, Tas., Jan., 1909, 2 males, 2 females. T'otal, 10 males, 5 females.

S. regiıa Selys-Sydney, N.S.W.,(Duck Creek, Auburn) Dec., 1905, 1 female; Feb., 1906, 1 female; Feb:, 1907, 5 males, 1 female; Jan., 1908, 3 males, 1 female; March, 1908, 1 female; April, 1908, 3 females; Dec., 1908, 1 female-Gladstone, Q., Jan., 1908, 1 male-Alexandia, Vic., Dec., 1906, 4 males, 1 female. Total, 13 males, 9 females. 
BY R. J. TILLYARD.

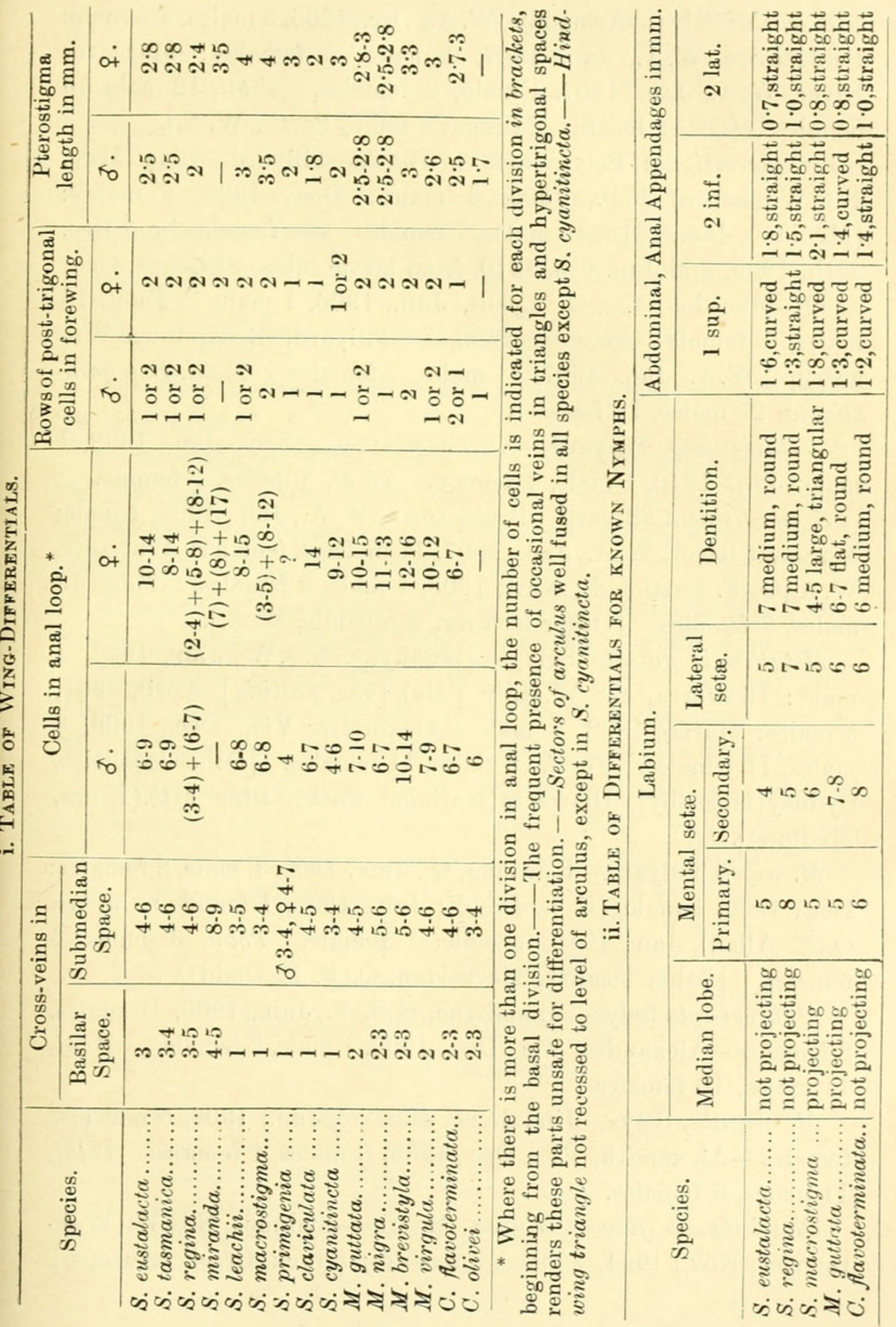


S. leachii Selys-Armadale, W.A., Dec., 1906, 3 males, 1 female: Bridgetown, W.A., Jan., 1907, 8 males, 3 females: Margaret River, W.A., Jan., 1907, 1 male, 2 females. Total, 12 males, 6 females. [Other locality, Mungar's Lake, Perth, W.A.].

S. macrostigma Selys, race orientalis Tillyard-Blue Mts., N.S.W.,(Leura) Feb., 1905, 3 males; Dec., 1908, 2 males: (Medlow), Jan., 1910, 10 males, 7 females; two females bred Dec. 26 th, 1909, and Jan. 6th, 1910, from larvæ taken at Leura, Oct., 1909-Macedon, Vic.(G. Lyell), Jan., 1906, 1 male. Total, 16 males, 9 females-Race occidentalis Tillyard, Bridgetown(Wilgarrup), W.A., Jan., 1907, 11 males, 3 females. Total, S. macrostigma, 27 males, 12 females.

S. claviculata Tillyard-Kuranda, Q.(E. Allen), Jan., 1908, 1 male; Jan., 1910, 1 male, 1 female. Total, 2 males, 1 female.

S. cyanitincta Tillyard-Bridgetown, W.A., Jan., 1907, 1 male: Margaret River, W.A., Jan., 1907, 11 males, 2 females: Waroona, W.A.(G. F. Berthoud), Nov., 1908, 1 male, 5 females. Total, 13 males, 7 females. [Other locality, A rmadale, W.A.].

Metathemis guttata Selys-Jindabyne, N.S.W., Jan., 1906, 1 male : Illawarra, N.S.W.(Lily Vale), [var. pallida], April, 1907, 3 males; March, 1908, 1 male-Alexandra, Vic., Dec., 1906, 8 males, 11 females. Total, 13 males, 11 females. [Other localities, Sydney(Hornsby), Illawarra(National Park), Blue Mts.(Leura, Medlow)].

M. nigra Tillyard-Kuranda, Q., Jan., 1905, 1 male, 2 females; Dec., 19c6, 1 male, (F. P. Dodd); Jan., 1908, 1 female: Cairns, Q.(E. Allen), Jan., 1910, 1 male, 1 female. Total, 3 males, 4 females. [Other locality, Herberton, Q.(F. P. Dodd)].

M. brevistyla Selys-Jindabyne, N.S.W., Jan., 1906, 10 males, 8 females-Alexandra, Vic., Dec., 1906, 1 male, 2 females. Total, 11 males, 10 females.

M. virgula, Selys_Jindabyne, N.S.W., Jan., 1906, 5 males, 2 females-Alexandra, Vic., Dec., 1906, 6 males, 4 females. Total, 11 males, 6 females.

Choristhemis flavoterminata Martin-Sydney, N.S.W.(Wahroonga), Nov., 1904, 4 males 3 females; (Duck Creek, Auburn), 
Dec., 1907, 1 male; Jan., 1908, 5 males; Dec., 1908, 1 male; (Hornsby), Dec., 1909, 4 males, 4 females: Illawarra, N.S.W. (Heathcote), April, 1909, 1 male, 2 females; Dec, 1909, 7 males, 1 female-Kuranda, Q., Nov., 1906, 1 male(F. P. Dodd): Cooktown, Q., Jan., 1908, 1 male, 1 female. Total, 25 males, 11 females. 「Other localities, Illawarra, N.S.W.(National Park), Sydney(Cheltenham), Brisbane, Q.(Enoggera Creek)].

C. olivei Tillyard-Cooktown, Q., Jan, 1908, 2 males.

List ii.(Mounted larvæ and exuviæ).

S. eustalacta Burm. -Blue Mts., N.S.W.(Leura), Nov., 1908, 18 specimens.

S. macrostigma Selys, race orientalis Tillyard-Blue Mts., N.S.W.(Leura), Nov., 1908, 5 specimens; (Medlow), Nov., 1909, 2 specimens: Illawarra, N.S.W.(National Park), Nov., 1908, 17 specimens. Total, 24 specimens.

S. regina Selys-Sydney, N.S.W.(Duck Creek, Auburn), Dec, 1908, 4 specimens; March, 1909, 1 specimen. T'otal, 5 specimens.

Metathemis guttata Selys-Blue Mts., N.S.W.(Leura), Nov., 1908, 6 specimens: (Medlow), Nov., 1909, 2 specimens: Sydney, N.S.W.(Hornsby), Dec., 1909, 1 specimen. Total, 9 specimens.

Choristhemis flavoterminata Martin - Illawarra, N. S. W. (Heathcote), Dec., 1909, 6 specimens: Sydney, N.S.W.(Cheltenham), Dec., 1909, 9 specimens: (Hornsby), Nov., 1909, 1 specimen. Total, 16 specimens.

EXPLANATION OF PLATES IV.-IX.

Plate iv, (all figs. $\times 2$ ).

Fig.1.-Synthemis eustalacta Burm. ठ.

Fig.2.-Synthemis tasmanica, n.sp. ठ .

Fig.3.-Synthemis regina Selys $\sigma$.

Fig.4. - Synthemis leachii Selys ठౌ.

Fig.5.-Synthemis macrostigma Selys ठð.

Fig.6.-Synthemis claviculata Tillyard o. 
Plate v.(all figs. $\times 2$ ).

Fig.7.-Synthemis cyanitincta Tillyard $\delta$.

Fig. 8. - Metathemis guttata Selys ơ.

Fig. 9.-Metathemis nigra Tillyard of.

Fig. 10._Metathemis brevistyla Selys ठ․

Fig.11.-Metathemis vir gula Selys ठో.

Fig. 12.-Choristhemis flavoterminata Martin ठ.

Fig. 13. - Choristhemis olivei Tillyard o .

Small figures-top, head seen from in front; second, colour-scheme of side of thorax,

Plate vi.(wing-venation; all figs. $\times 9$ ).

Fig.1._Choristhemis olivei ठో hindwing; anal loop, arculus and triangle.

Fig.2.- ,, flavoterminata ठَ ,,

Fig.3.-Synthemis eustalacta ठ , ,

Fig.4.--Synthemis eustalacta $q$, ,

Fig.5.--Synthemis cyanitincta of ",

Fig.6.-Metathemis guttata ठ $\quad$,

Fig.7.-Synthemis macrostigma ठ, ,

Fig. 8. - Synthemis macrostigma $q$,

Fig.9.-Synthemis regina ơ ,

Fig.10.-Synthemis regina + , ,

\begin{tabular}{|c|c|c|}
\hline , &, & , \\
\hline , &, &, \\
\hline , & , & , \\
\hline , , & , & , \\
\hline , , & , &, \\
\hline , , & , &, \\
\hline , & ,", &, \\
\hline , & , , & , \\
\hline , , &, , &, , \\
\hline
\end{tabular}

Fig.11.-Synthemis lecichii $\delta$, freak-venation of forewing in region of triangle.

Fig.12.-Synthemis cyanitincta 9 , freak-venation of forewing in region of triangle.

Fig.13.-Synthemis regina ðَ, pterostigma.

Fig.14.-Synthemis claviculata ठै, pterostigma.

Fig. 15. - Synthemis macrostigma $\sigma^{\vec{\gamma}}$, pterostigma.

Fig. 16. - Synthemis regina, freak-venation of hindwing in region of triangle.

A, anal vein; arc., arculus; b, brace; C, costal vein; Cu., cubitus; h, hypertrigonal space; $\mathrm{m}$, membranule; $\mathrm{P}$, pterostigma; $\mathrm{R}+\mathrm{M}$, radius + median; t, triangle.

Plate vii.(appendages, etc., figs. $1.23, \times 9$ ).

Fig. 1.-Synthemis eustalacta $\precsim$, anal appendages, $a$ dorsal, $b$ profile view.

Fig. 2 - Synthemis tasmanica ठో

Fig.3.-Synthemis regina ठ

Fig. 4. - Synthemis macrostigma ठ

Fig. 5.-Synthemis leachii ठ

Fig.6. - Synthemis claviculata ठ

Fig.7.-Synthemis primigenia ठ

$\begin{array}{ccc},, & ,, & ,, \\ ,, & ,, & , \\ ,, & ,, & ,, \\ ,, & ,, & ,, \\ ,, & ,, & \text { (after Martin). }\end{array}$


Fig. 8. - Synthemis cyanitincta $\delta$, anal appendages, $a$ dorsal, $b$ profile view.

Fig.9. - Metathemis brevistyla ठ

Fig. 10. - Metathemis virgula ठ

Fig. 11.-Metathemis guttaia $ठ$

Fig.12._Metathemis nigra ठ

Fig. 13.-Choristhemis flavoterminata ठ ,,

Fig. 14._Choristhemis olivei ठ

Fig. 15. - Choristhemis flavoterminata ठ, profile view of segment 2, underside,

Fig.16.-Synthemis regina + , last three segments of abdomen, a profile, $b$ ventral view.

Fig 17. - Synthemis maerostigma + , last three segments of abdomen, profile view.

Fig.18. - Synthemis leachii 9 , last three segments of abdomen, profile view.

Fig. 19.-Synthemis eustalacta $q$

Fig.20.-Synthemis tasmanica 우

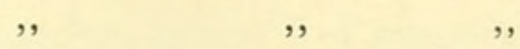

Fig.21.-Synthemis cyanitincta $q$, last three segments of abdomen, a profile, $b$ ventral view.

Fig 22. - 'horisthemis flavoterminata $q$, last three segments of abdomen; $a, b, c$, profile views of three different females; $d$, ventral view of $a$.

Fig.23.- Metathemis virgula $q$, last three segments of abdomen, ventral view.

Fig.24. - Synthemis eustalacta ठ, penis $(\times 25)$.

Fig.25.-Metathemis guttata $ठ$, penis ,,

Fig. 26. - Choristhemis flavoterminata $\delta$, penis $(\times 25)$.

Plate viii.(larvæ).

Fig. 1. - Part of egg-cluster of Synthemis eustalacta Selys $(\times 10)$.

Fig.2.-Full-grown nymph of Synthemis eustalacta Selys $(\times 4)$.

Fig.3. - Head of Synthemis eustalacta Selys, seen from in front $(\times 9)$.

Fig.4. - Antennæ of Synthemis eustalacta Selys $(\times 25)$.

Fig.5.- Head of Metathemis guttata Selys, from above $(\times 9)$.

Plate ix.(labia of nymphs).

Fig. 1.-Labium of Synthemis eustalacta Selys $(\times 25)$.

Fig.2.-Labium of Synthemis regina Selys $(\times 25)$.

Fig.3.-Labium of Synthemis macrostigma Selys $(\times 25)$.

Fig.4.-Labium of Metathemis guttata Selys ( $\times 25$ ).

Fig.5.-Labium of Choristhemis flavoterminata Martin ( × 25). 


\section{$2 \mathrm{BHL}$ Biodiversity Heritage Library}

Tillyard, R. J. 1910. "Monograph of the genus Synthemis. [Neuroptera:

Odonata]." Proceedings of the Linnean Society of New South Wales 35, 312-377. https://doi.org/10.5962/bhl.part.25547.

View This Item Online: https://www.biodiversitylibrary.org/item/21738

DOI: https://doi.org/10.5962/bhl.part.25547

Permalink: https://www.biodiversitylibrary.org/partpdf/25547

\section{Holding Institution}

MBLWHOI Library

\section{Sponsored by}

MBLWHOI Library

\section{Copyright \& Reuse}

Copyright Status: NOT_IN_COPYRIGHT

This document was created from content at the Biodiversity Heritage Library, the world's largest open access digital library for biodiversity literature and archives. Visit BHL at https://www.biodiversitylibrary.org. 